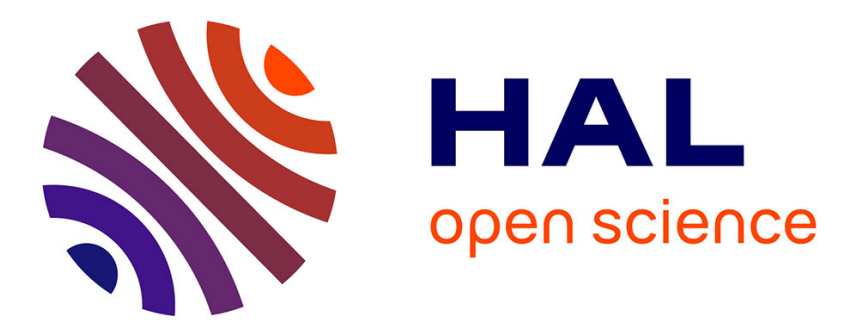

\title{
Refining adjuvant therapy for non-metastatic colon cancer, new standards and perspectives
}

\author{
Julien Taieb, Thierry André, Edouard Auclin
}

\section{To cite this version:}

Julien Taieb, Thierry André, Edouard Auclin. Refining adjuvant therapy for non-metastatic colon cancer, new standards and perspectives. Cancer Treatment Reviews, 2019, 75, pp.1 - 11. 10.1016/j.ctrv.2019.02.002 . hal-03484647

\section{HAL Id: hal-03484647 \\ https://hal.science/hal-03484647}

Submitted on 20 Dec 2021

HAL is a multi-disciplinary open access archive for the deposit and dissemination of scientific research documents, whether they are published or not. The documents may come from teaching and research institutions in France or abroad, or from public or private research centers.
L'archive ouverte pluridisciplinaire HAL, est destinée au dépôt et à la diffusion de documents scientifiques de niveau recherche, publiés ou non, émanant des établissements d'enseignement et de recherche français ou étrangers, des laboratoires publics ou privés.

\section{다)(1) $(5$}

Distributed under a Creative Commons Attribution - NonCommercial| 4.0 International 


\section{Refining adjuvant therapy for non-metastatic colon cancer, new standards and perspectives}

Julien Taieb ${ }^{1,3}$, Thierry André3, Edouard Auclin ${ }^{1,4,5}$

Affiliation

1 Sorbonne Paris-Cité, Paris Descartes university, hepatogastroenterology and Gastrointestinal oncology department, Hôpital Européen Georges Pompidou, Paris, France

2 INSERM UMR-S1138, CNRS SNC5014, Paris Descartes University, Equipe labellisée Ligue Nationale contre le cancer, Paris, France.

3 Sorbonne University and Medical Oncology department, Hôpital Saint Antoine, Paris

4 Methodology and quality of life unit in oncology, University hospital of Besançon, Besançon, France

5 Univ. Bourgogne Franche-Comté, INSERM, EFS BFC, UMR1098, Interactions Hôte-Greffon-Tumeur/Ingénierie Cellulaire et Génique, F-25000 Besançon, France;

Corresponding author: Prof Julien Taieb, Service d'Oncologie digestive, Hôpital Européen Georges Pompidou, 20 rue Leblanc, 75015 Paris France. Jtaieb75@gmail.Com

Keywords : colon cancer, adjuvant, survival, prognosis

Acknowledgment : the Association des Gastroentérologues Oncologues (AGEO) funded the English language corrections. 


\section{Abstract}

Colon cancer is the third most frequent cancer in males and the second in females. Approximately $75 \%$ are diagnosed at a localized stage. Recurrence occurs in $30 \%$ of patients when there is nodal involvement (stage III) due to micrometastatic spreading. To date only chemotherapeutic drugs such as fluoropyrimidines or oxaliplatin have proven effective to kill this residual disease and are currently recommended by scientific societies. To improve patient management in the near future, recent research has focused on new ways of using currently available agents, tools to better define each individual patient prognosis more clearly so as to tailor adjuvant treatment, and molecular profiling to identify specific subgroups of patients with tumors that may benefit from specific therapeutic approaches. In this review, we will focus on current scientific knowledge on adjuvant treatment in localized colon cancer, the duration and timing of adjuvant therapy and the perspectives for better selection of patients who will benefit from adjuvant treatments. 


\section{4 words}

\section{Introduction}

With 1360802 new cases worldwide in 2012, colon cancer is the third most frequent cancer in males and the second in females (1). More than $95 \%$ are adenocarcinoma, and $75 \%$ are diagnosed at a localized stage(2). Even diagnosed at a localized stage, recurrence occurs in $30 \%$ of patients when there is nodal involvement (stage III) due to micrometastatic spreading. Hence, research has sought effective post-surgery treatments to kill this residual disease. To date only chemotherapeutic drugs such as fluoropyrimidines or oxaliplatin have proven effective and are currently recommended by scientific societies $(2,3)$. However, while these treatments are saving thousands of lives each year, they are also associated with short- and long-term toxicities and are only useful for 15 to $25 \%$ of treated patients, meaning than more than $70 \%$ of patients receive chemotherapy without benefit and with toxicity.

To improve patient management in the near future, recent research has focused on new ways of using currently available agents, tools to better define each individual patient prognosis more clearly so as to tailor adjuvant treatment, and molecular profiling to identify specific subgroups of patients with tumors that may benefit from specific therapeutic approaches.

In this review, we will focus on current scientific knowledge on adjuvant treatment in localized colon cancer, the duration and timing of adjuvant therapy and the perspectives for better selection of patients who will benefit from adjuvant treatments. 


\section{Stages I and II colon cancer}

Stage I colon cancer is defined as a tumor invading at worst the muscularis propria of the colon (pT1-2NOM0). A consensus has been found for these tumors: no adjuvant chemotherapy is recommended as 5 -year overall survival (OS) is an estimated $85-95 \%$ with surgery alone $(2,3)$.

Stage II colon cancer is defined as a tumor invading at worst adjacent organs but without any nodal involvement (pT3-4NOM0). Stage II colon cancer covers a very heterogeneous group of patients. Indeed, 5-year survival varies between $58.4 \%$ for stage Ilc (adjacent organ invasion) disease and $87.5 \%$ for stage lla disease (T3-N0) (4). When considering the whole stage II population, the benefit of adjuvant chemotherapy is debated. Data come mainly from the QUASAR study, the NSABPC01-02 studies and the IMPACT-B2 meta-analysis(5,6).

In the IMPACT B2 meta-analysis, adjuvant chemotherapy did not benefit stage II colon cancer (6). A total of 1016 patients from 5 randomized trials were included in this study. The 5 -year OS rate was $82 \%$ in the $5 \mathrm{FU} / \mathrm{LV}$ group and $80 \%$ in the control group (HR: $0.86,90 \% \mathrm{Cl}: 0.68-1.07, \mathrm{p}=0.057$ ) and the 5 -year event-free survival was $76 \%$ in the chemotherapy group and $73 \%$ in the surveillance group (HR: $0.83,90 \%$ $\mathrm{Cl}: 0.72-1.07)$. However, the differences were not significant.

Contradictory results were obtained with the subgroup analysis of stage II patients enrolled in the NSABP C01 and 02 studies(7-9). NSABP C01 and C02 compared adjuvant chemotherapy to surgery alone in 1409 patients with colon cancer, among whom 705 had stage II colon cancer. While NSABP C01 did not show any benefit of adjuvant chemotherapy in terms of OS (5-year OS rate $75 \%$ vs $72 \%$ for chemotherapy and surgery groups, respectively, $p=0.73$ ), NSABP C02 showed the superiority of perioperative portal venous infusion compared with surgery alone in stage II colon cancer (5-year OS $88 \%$ vs $76 \%$ for chemotherapy and surgery groups, respectively, $p=0.005)$. The QUASAR study randomized 3239 patients with localized colon and rectal cancer between 5FU-based adjuvant chemotherapy and postoperative observation (5). Stage II patients represented $91 \%$ of the whole population ( $n=1483$ in the chemotherapy arm and $n=1480$ in the observation arm). In the subgroup analysis of the stage II population, the study showed a benefit for 
adjuvant chemotherapy in terms of relative risk of recurrence, which decreased by 29\% (HR: $0.71,95 \% \mathrm{Cl}: 0.54-0.92, \mathrm{p}=0.01$ ), with a trend for better OS (HR: 0.83, $95 \% \mathrm{Cl}: 0.65-1.07)$. However, the absolute benefit of adjuvant fluoropyrimidine was only $2.9 \%$, leading in many countries to an absence of consensus regarding whether or not to treat these patients. In the patients included in the QUASAR study, the median number of lymph nodes examined was only 6, indicating that the QUASAR population almost certainly had a large population of undiagnosed stage III patients (5). Likely due to enhanced accuracy of staging, recurrence rates have fallen significantly over time in clinical trials that included patients with stage II disease with identical treatment, reflecting stage migration over time.

Finally, the 10-year update of the MOSAIC study showed no statistical benefit in adding oxaliplatin to LV5FU2 in stage II colon cancer in terms of disease-free survival (DFS) or OS, even in patients with poor prognostic factors such as tumor stage T4, bowel perforation and/or fewer than 10 nodes examined (HR for DFS: 0.79 , 95\% Cl: 0.55-1.13, and HR for OS: 0.89, 95\% Cl: 0.60-1.32) $(10,11)$.

We should highlight that all these results are from subgroup analyses of phase III trials, and no specific trial has been designed to answer the stage II colon cancer question directly. Moreover, the combination of 5FU plus oxaliplatin has never been compared with surgery alone.

In the light of these results and the $2-5 \%$ improvement of survival with adjuvant chemotherapy in stage II colon cancer, adjuvant treatment for stage II colon cancer is indicated according to tumor-related prognostic factors and should be balanced against patient comorbidities and life expectancy.

Recently, the major prognostic value of mismatch repair (MMR) status in resected stage II colon cancer led to the recommendation that MMR status should be determined in those patients and that no adjuvant chemotherapy should be administered to deficient MMR (dMMR) stage II patients, whatever the other risk factors $(3,12)$. In proficient MMR (pMMR) tumors, adjuvant chemotherapy is nowadays discussed individually for patients with risk factors for relapse, defined with a consensus for T4-stage, bowel perforation, number of nodes examined $<12$, and 
without a clear consensus for vascular, perineural or lymphatic invasion, undifferentiated tumor and obstruction $(2,3)$. 


\section{Stage III colon cancer}

Unlike in stage II colon cancer, the situation is clearer for stage III colon cancer. Indeed, adjuvant treatment is recommended for all patients $(2,3)$. Fluoropyrimidine-based chemotherapy is the standard adjuvant treatment. It decreases the risk of death by $10-15 \%$ when fluorouracil monotherapy follows surgical resection, and by $20-22 \%$ when it is used in combination with oxaliplatin (Figure 1).

It has been known since the 1990s that fluorouracil monotherapy is beneficial versus observation after surgical treatment of stage III colon cancer (13). In this study, Moertel et al found that adjuvant fluorouracil and levamisole decreased the relative risk of recurrence by $41 \%$, and at 3.5 years the DFS was $16 \%$ higher in the adjuvant chemotherapy group compared with the observation group. Similar results were observed with other fluoropyrimidine-based regimens, showing a benefit of $12-16 \%$ in terms of 5 -year OS $(5,6,11,14)$. The LV5FU2 regimen was finally preferred to the FUFOL regimen because of its better tolerability profile and good efficacy $(15,16)$. Oral fluoropyrimidines have also been assessed in this setting. The X-ACT trial compared capecitabine with 5FU/LV (Mayo Clinic regimen) as adjuvant therapy for stage III colon cancer $(17,18)$. This trial randomized 1987 patients with stage III colon cancer ( $n=1004$ in the capecitabine group, $n=983$ in the 5FU group). The analysis of the primary endpoint (DFS) showed that capecitabine was not inferior to 5FU (HR: $0.87,95 \% \mathrm{Cl}: 0.75-1.00$ ), with a trend toward superiority for capecitabine ( $\mathrm{p}$ value for planned superiority analysis: 0.05). The same results were obtained for OS (HR: 0.86, $95 \% \mathrm{Cl}: 0.74-0.99, \mathrm{p}$ value for superiority: 0.07 ). Safety analysis showed significantly fewer adverse events in the capecitabine arm than in the fluorouracil plus leucovorin arm $(\mathrm{p}<0.001)$, except for hand-foot syndrome. Tegafur-uracil, an oral pro-drug of 5FU, also showed some efficacy in the adjuvant setting $(19,20)$, but is no longer available in most countries. Recently, another oral fluoropyrimidine called tegafur-gimeracil-oteracil potassium (or S1) was compared with capecitabine (21). In this Japanese non-inferiority phase III trial, 1564 patients were randomly assigned to 
capecitabine $(n=782)$ or $S-1 \quad(n=782)$. S-1 failed to show its non-inferiority with a 3year DFS of $82 \%$ for the capecitabine group and $78 \%$ for the S-1 group (HR 1.23, $95 \% \mathrm{Cl}$ 0.89-1.70; one-sided $\mathrm{p}$ non-inferiority $=0.46$ ). Capecitabine thus remains the only oral alternative to intravenous $5 \mathrm{FU}$ as adjuvant treatment for stage III colon cancer, outside Asia, where $\mathrm{S} 1$ is available in this indication.

Addition of oxaliplatin to $5 \mathrm{FU}$ and folinic acid has been tested in 2 main randomized control trials: MOSAIC and NSABP C07 $(10,22)$. In the stage III population of the MOSAIC trial, addition of oxaliplatin to LV5FU2 increased 10-year OS by $8.1 \%$ (HR: $0.80,95 \% \mathrm{Cl}: 0.66-0.96, p=0.016$ ). This OS improvement was greater in the N2 population (absolute 10-year OS increase of 12.9\%, HR: $0.70,85 \%$ Cl: $0.53-0.93, p=0.013)$. The same results were seen in the NSABP C07 trial, where oxaliplatin in addition to fluorouracil increased 3-year DFS by $6.6 \%$ (22). The superiority of XELOX (capecitabine and oxaliplatin) over bolus 5FU/LV as adjuvant treatment for stage III colon cancer was shown in the 1886 patients of the NO16968 trial (23). Haller et al reported a 3-year DFS of $71.0 \%$ for capecitabine/oxaliplatin vs. $67.0 \%$ for $5 F U$ bolus/LV (HR 0.80, $\mathrm{p}=.0045)(24)$

Finally, a meta-analysis of 5 randomized trials confirmed in 12233 patients that addition of oxaliplatin to fluoropyrimidines had a significant positive impact on outcomes in stage III patients (25). However, this gain in survival is balanced by an increase in treatment-related toxicities and particularly $12 \%$ of grade 3 sensory neuropathy induced by oxaliplatin at the end of the 6 months of adjuvant therapy (11). These results were replicated with the combination of capecitabine and oxaliplatin, and thus both FOLFOX and CAPOX regimens are nowadays considered as standard adjuvant treatments for stage III colon cancer (23).

The addition of irinotecan to fluorouracil has been tested in 3 trials, all negative (2628). 
Attempts to improve adjuvant treatment of stage III disease by adding targeted agents such as cetuximab and bevacizumab have also been unsuccessful (29-33). The C-08 study found that a one-year bevacizumab adjuvant treatment in combination with FOLFOX did not significantly improve DFS (HR: $0.89,95 \% \mathrm{Cl}$ : $0.76-1.04, p=0.15)(29,30)$. The authors also underlined the fact that there was a trend to a benefit of bevacizumab during the first 15 months, suggesting that it could help control residual disease but not eradicate it. In the AVANT study, there was a trend to a detrimental effect of the addition of bevacizumab to FOLFOX in terms of DFS (HR: 1.17 ; 95\% Cl: 0.98-1.39, $p=0.07$ ), and to CAPOX (HR:1.07; 95\% Cl: 0.90$1.28, \mathrm{p}=0.44)(31)$.

Similar results were obtained with the addition of cetuximab $(32,33)$. The PETACC8 study found no difference between FOLFOX and FOLFOX+cetuximab, the 3-year DFS rates being $79.1 \%$ in the FOLFOX arm and $75.9 \%$ in the cetuximabFOLFOX arm (HR:0.99, 95\% Cl: 0.76-1.28, $\mathrm{p}=0.92$ ) in the KRAS wild-type population (33). However, when looking at patients wild-type for KRAS/NRAS and BRAF in a post-hoc analysis, there was a trend to cetuximab efficacy (adjusted HR: 0.70; 95\% Cl: 0.48-1.03, $\mathrm{p}=0.07)(34)$.

In summary, in stage III colon cancers 50 to $60 \%$ of patients are cured by surgery alone, $20 \%$ with addition of adjuvant chemotherapy, and 20 to $30 \%$ will experience recurrence (2) (Figure 1). To date the only chemotherapy regimens having shown improved survival are fluoropyrimidines alone or in combination with oxaliplatin, Table 1. 


\section{Timing and duration of adjuvant treatments}

The interval between surgery and the beginning of adjuvant chemotherapy is codified. A meta-analysis of 14 studies showed that an interval above 8 weeks increased the relative risk of death (HR: $1.20,95 \% \mathrm{Cl}: 1.15-1.26, p=0.001$ ) (35). These results corroborate those of Hershman et al in 2006 (36), who found in more than 4000 patients with stage III colon cancer from the SEER database that colon cancer-specific mortality was associated with a time until initiation of adjuvant chemotherapy of more than 3 months (HR 1.48, 95\% Cl: 1.15-1.92). Finally, many population-based studies have shown that even though starting adjuvant chemotherapy before 8 weeks is ideal, it might still be useful even with a longer interval, with a maximum of 5 to 6 months depending on the study (37-39). For example, Gao et al found, in a SEER database cohort of 18491 patients with stage III colon cancer, that there was still a benefit of adjuvant chemotherapy 17 weeks after surgery when compared with patients who did not have adjuvant treatment (37). This benefit in terms of OS became nonsignificant after 21 weeks between surgery and adjuvant treatment onset (37). Possible bias in these results relates to post-operative complications, patient comorbidities, emergency surgery in patients whose adjuvant chemotherapy was initiated more than 8 weeks after surgery. These factors can per se explain the longer wait until adjuvant therapy together with the lower survival rates observed in these patients. Pending better studies, it is recommended to start adjuvant chemotherapy ideally within 8 weeks after surgery.

Except for fluoropyrimidines and oxaliplatin, no anticancer agents in the metastatic setting have proven effective in the adjuvant setting in the last 15 years, and so physicians and researchers have tried to modify the timing and duration of this doublet standard, to improve patient outcomes and decrease treatment-related toxicity. Two main strategies have been developed: use chemotherapy perioperatively instead of postoperatively only and shorten treatment duration to spare toxicity and health-related costs.

Important results from the IDEA project were presented in 2017 at the ASCO and ESMO meetings. The IDEA project pooled the analysis of 6 large randomized controlled trials (4 from Europe, one from Japan and one from the US) that compared 
3 versus 6 months of adjuvant standard treatment with a doublet of fluoropyrimidines and oxaliplatin (FOLFOX or CAPOX) (40).

We should highlight that IDEA is not the first study to raise the question of optimal adjuvant treatment duration in colon cancer. Previous attempts to reduce adjuvant chemotherapy duration from 12 to 9 and then to 6 months have been successful (15,41-44). Four studies showed that a 6-month fluoropyrimidine-based adjuvant treatment was not inferior to longer treatment duration. For example, André et al found, in stage II and III colon cancer, no difference in terms of DFS and OS between 24 weeks $(n=454)$ and 36 weeks $(n=451)$ of treatment, with an HR of 0.942 (95\% Cl: 0.73-1.21 p=0.63) and 1.28 (95\% Cl: 0.90-1.80 p=0.17) for DFS and OS, respectively (15). Similarly, Sadahiro et al found no difference between 6 months $(n=534)$ and 18 months $(n=537)$ with oral uracil/tegafur+leucovorin in terms of DFS and OS with HR:1.00 (95\% Cl: 0.80-1.24, p=0.98) and HR 1.05 (95\% Cl: 0.78-1.42, $\mathrm{p}=0.07$ ) for DFS and OS, respectively (41).

Six-month adjuvant treatment being considered as the standard duration, Chau et al compared a 3-month protracted venous infusion (PVI) of 5FU ( $n=397)$ with 6-month 5FU/LV ( $\mathrm{n}=401)$ (44) They reported that 3 months of $\mathrm{PVI} 5 \mathrm{FU}$ was associated with a trend to better survival (HR: $0.7995 \% \mathrm{Cl}$ : $0.61-1.03 p=0.08$ ). However, in the control arm, 5FU/LV was not optimally administered as it was 5FU $425 \mathrm{mg} / \mathrm{m}^{2}$ on days $1-5$ every 4 weeks.

The IDEA project randomized a total of 12834 patients (40), 2402 of whom were included in the TOSCA study (Italy), 3983 in the SCOT study (UK, Denmark, Spain, Australia, Sweden, New Zealand), 2010 in the IDEA France study (France), 2440 in the CALGB/SWOG study (USA, Canada), 708 in the HORG study (Greece), and 1291 in the ACHIEVE study (Japan) (45-49). CAPOX was administered to $39.5 \%$ of patients (from $0 \%$ in the US trial to $75.1 \%$ in the Japanese trial), and $41.3 \%$ of the patients had T4 and/or N2 disease (from 34.5\% in the TOSCA study to $49 \%$ in the SCOT study). The primary endpoint of these 6 trials was non-inferiority in terms of DFS of 3 versus 6 months of adjuvant treatment.

With a median follow-up of 41.8 months, non-inferiority of 3 months of therapy versus 6 months was not confirmed in the modified intent-to-treat population (HR 
$1.07 ; 95 \% \mathrm{Cl}: 1.00-1.15 \mathrm{p}=0.11)$. These results should be interpreted in the light of the preplanned subgroup analysis depending on the $\mathrm{T}$ and $\mathrm{N}$ stages and of adjuvant regimens (CAPOX vs FOLFOX), but not preplanned low- (T1-3N1 patients) and highrisk groups (T4 and/or N2). In the low-risk group (T1-3N1 patients), 3 months of CAPOX was not inferior to 6 months of CAPOX (3y DFS $85 \%$ and $83.1 \%$ for the 3 and 6 months groups, respectively, HR: $0.8595 \% \mathrm{Cl}: 0.71-1.01)$, Table 2. However, the non-inferiority was not proven for 3 months of FOLFOX in these patients $(81.9 \%$ and $83.5 \%$ for the 3 - and 6-month groups, respectively, $\mathrm{HR}: 1.1095 \% \mathrm{Cl}: 0.96-1.26$ ) Table 2. Continuous exposure to $5 \mathrm{FU}$ is one of the hypothesis for this difference, as suggested in the study from Chau et al with PVI FU (44). If we consider the high-risk population (T4 and/or N2), 3 months of adjuvant treatment was inferior to 6 months (Table 2). In detail, the non-inferiority was not proven for CAPOX with 3y DFS of $64.1 \%$ and $64.0 \%$ for the 3- and 6-month groups, respectively (HR: $1.0195 \% \mathrm{Cl}$ : 0.89-1.17), and 6-month FOLFOX was superior to 3 months, with 3y DFS of $61.5 \%$ and $64.7 \%$ for the 3 - and 6-month groups, respectively (HR: $1.2095 \% \mathrm{Cl}: 1.07-1.35$ ). These subgroup analyses involve a large number of patients, and can therefore be interpreted reliably. There was no randomization between the FOLFOX and CAPOX regimens and thus patients selected for one or other regimen may have differed in terms of comorbidities, physical activity and other important prognostic factors. Moreover, dose intensity results concerning capecitabine in the 6-month CAPOX arm, are missing. Questions are raised by the higher DFS rates of patients receiving 3 months of CAPOX as compared to the patients receiving 6 months of CAPOX (85 vs $83.1 \%$ ), with the same rate of treatment-related death in both groups.

Based on these results, clinical guidelines were changed and recommend 3 months of CAPOX adjuvant treatment for low-risk stage III colon cancer ( 3 months of FOLFOX being an option for patients not able to receive capecitabine), and 6 months of FOLFOX treatment for high-risk stage III colon cancer ( 6 months of CAPOX being an option) (2).

Beyond efficacy results, the IDEA project showed that a reduced duration of adjuvant chemotherapy was associated with a substantial reduction in long-term side effects and a significant reduction in health-related costs. The safety analysis of the IDEA France trial showed that reducing the adjuvant chemotherapy duration resulted 
in a decrease of $13 \%$ and $23 \%$ in Graded 2 and $3 / 4$ maximal peripheral sensory neuropathy (PSN) in the overall population (46). Moreover, patients receiving the 6 months of treatment experienced significantly more residual PSN 3.6 years after randomization, with $8 \%$ of Grade $>1$ residual PSN as compared to $2.5 \%$ in the 3 months arm $(p<0.001)$. The same kind of results were obtained in the SCOT, ACHIEVE and TOSCA trials (47-49). More than PSN, all grade 3 adverse events were significantly reduced in the 3 months arm $(29 \%$ versus $56 \%$ in the IDEA France study, $29 \%$ versus $43 \%$ in the ACHIEVE study) $(46,47)$. The safety analysis of the IDEA France and TOSCA trials found that grade $3+$ neutropenia was also significantly more frequent ( $17 \%$ versus $12 \%, p=0.005$; and $27.6 \%$ vs $20.7 \%$, $\mathrm{p}<0.0001$ for the IDEA France and TOSCA trials, respectively) in the 6 months arm, as were diarrhea and allergic reactions $(46,49)$.

Considering the best schedule to administer chemotherapy in operable colon cancer and due to the success of pre- or perioperative treatment strategies in many Gl cancers (esophageal, gastric, rectal, colorectal liver metastasis), three studies were designed to assess the efficacy of perioperative chemotherapy in this setting (50-52). The ongoing phase III FOxTROT study (NCT00647530) has yielded preliminary feasibility results on 150 patients randomized between perioperative chemotherapy ( $n=99)$ and upfront surgery $(n=51)$ (50). In the perioperative chemotherapy group, there were more $\mathrm{R} 0$ resections ( $96 \%$ versus $80 \%, \mathrm{p}=0.002$ ). The treatment was feasible with identical complication rates between the groups and $83 \%$ of the patients in the perioperative group started postoperative chemotherapy. The second trial, Prodige 22 (NCT01675999), is a randomized phase II trial assessing the efficacy and feasibility of FOLFOX in a perioperative strategy in patients with localized stage III disease or high-risk II ( $n=52$ in the perioperative FOLFOX arm, $n=52$ in the adjuvant FOLFOX arm) (52). The primary endpoint was the rate of high tumor regression grade (TRG). The Prodige 22 trial showed that perioperative FOLFOX in patients with locally advanced nonmetastatic colon cancer does not increase post-surgery morbidity and is associated with a significantly higher TRG compared with upfront surgery (TRG1-2 44\% in the neoadjuvant chemotherapy group versus $8 \%$ in the upfront surgery group). Finally, Jakobsen et al found similar results in another randomized phase II trial comparing neoadjuvant CAPOX+panitumumab to neoadjuvant CAPOX treatment alone (51). The aim of this 
last study was to assess whether neoadjuvant chemotherapy was able to convert high-risk patients into low-risk and to explore the effect of the addition of anti-EGFR therapy. Among the 71 patients included in the study, 48\% experienced downstaging, even if the addition of panitumumab did not result in a higher rate of downstaging. However, the neoadjuvant chemotherapy may also lead to the risk of progression before surgery (11\% in the Jakobsen study, but only $2 \%$ in Prodige 22$)$. Moreover, there is no clear consensual recommendation concerning baseline staging for these patients, especially the staging of nodal status, and the risk to over-stage patients is an issue here. We still have to explore the best way to stage these patients using only CT-scans or MRI and TEP-scans together with the best radiological criteria to avoid over-staging and exposure of some of them to a useless preoperative treatment.

Though these pilot trials showed the feasibility and good tolerability of preoperative chemotherapy in locally advanced nonmetastatic colon cancers, we have to wait for the results of ongoing phase III trials before determining whether this approach can be used in our daily practice and for which patients. 


\section{Adjuvant treatment in elderly patients}

Sargent et al showed in 2001 the benefit of adjuvant chemotherapy (versus no chemotherapy) in elderly patients with localized colon cancer (53). In this pooled analysis of 7 randomized trials, they included 1269 patients, aged 60 to 70 years, and 506 patients older than 70 years. Adjuvant chemotherapy seemed to benefit patients over 70 in terms of recurrence-free survival and OS, but no statistical comparison was available concerning this population. No significant interaction was observed between age and the efficacy of treatment. The incidence of toxic effects was not increased among the elderly (age $>70$ ), except for leukopenia in one study (53). These results were corroborated by a smaller analysis of a German randomized trial (54).

Concerning the benefit of addition of oxaliplatin to fluoropyrimidines, a pooled analysis of the NSABP C-08, XELOXA, X-ACT, and AVANT studies led by Haller et al suggested a benefit in terms of DFS and OS for addition of oxaliplatin to $5 \mathrm{FU}$ in elderly patients (aged $>70)(n=1119, H R=0.9495 \% \mathrm{Cl}: 0.78-1.13$ for DFS and $\mathrm{HR}=1.0495 \% \mathrm{Cl}: 0.85-1.27$ for OS) (55). However, this benefit was not found in other studies $(22,56-58)$.

In the studies assessing the benefit of adjuvant chemotherapy, elderly patient numbers were low and selection bias may limit the interpretation of the study results in the elderly population. Consideration of patient comorbidities is a key point in decision-making regarding adjuvant treatment in elderly patients with colon cancer.

In summary, elderly patients do benefit from adjuvant chemotherapy, but may benefit less from addition of oxaliplatin than younger patients. The decision to administer adjuvant treatment should be made according to patient comorbidities, performance status and life expectancy. The PRODIGE 34-ADAGE trial (NCT02355379) is currently recruiting patients in order to assess the benefit of adjuvant chemotherapy + /- oxaliplatin in patients over 70 who have stage III colon cancer. 


\section{Prognostic and predictive markers}

The best way to improve adjuvant treatment in colon cancer is to define prognostic groups better and to find predictive markers of the benefit of adjuvant treatment. In this perspective, many pathological, biological, and molecular factors have been studied during the last decade.

Carcinoembryonic antigen (CEA) has been largely studied in localized colon cancer. Konishi et al showed that postoperative levels of CEA were more relevant than preoperative levels (59). Moreover, the cut-off, usually set at $5 \mathrm{ng} / \mathrm{mL}$, is debated (60-63). A cut-off point between 1.30 and 3 was found to be more relevant in various studies in stage I-III colon cancer (62). However, no predictive value of CEA was found for adjuvant chemotherapy benefit and this low-cost marker seems only useful for prognostication in localized disease.

Supervised prognostic genomic signatures have been developed to summarize the prognostic information provided by molecular factors. The main genomic signatures have been widely analyzed in both retrospective and prospective studies, including Oncotype Dx Colon Cancer®, ColoPrint $\AA^{\circledR}$, Veridex® and GeneFx Colon® (64-66). Most validation studies have focused on stage II disease, but several included stage III disease, especially using the Oncotype Dx Colon Cancer $\AA$ signature (64). The accuracy of these scores is controversial, as they currently do not allow us to guide our treatment decision because their prognostic discrimination capacity is insufficient.

Immunologic features have been studied in order to define prognosis better (67-71). The Immunoscore $®$ developed by Galon et al is currently the most studied (70) and has recently been validated prospectively, using a predefined statistical hypothesis, in a large trial population of stage III patients with MSI assessment (72). However, this validation did not include other important prognostic factors such as CEA level, BRAF and RAS mutational status, and adjuvant standard treatment for all patients. Moreover, the accuracy of the Immunoscore ${ }^{\circledR}$ was not perfect, as the c- 
index for DFS prediction was 0.58 . Clinical trials are needed to assess the decisionmaking utility of Immunoscore $\AA^{\circledR}$ in guiding therapeutic decision-making. In this setting, first results were presented this year at the ASCO GI 2019 symposium. In a cohort of 1130 patients with untreated stage II colon cancer, Galon et al showed that high risk patients with high Immunoscore ${ }^{\circledR}$ had similar time to recurrence compared with with low risk stage II patients (73). However, precisions concerning the patients included and the impact of Immunoscore ${ }^{\circledR}$ on treatment outcome are needed in order to validate its decision making utility. These immunological tools could also be of interest in future immunotherapy trials in the adjuvant setting.

The analysis of large phase III trials has increased our understanding of the prognosis of patients with stage III colon cancer. Recently, KRAS and BRAF mutations together with a methylator phenotype (CIMP) were found to be independently associated with shorter DFS, survival after recurrence, and OS (7477).

Other molecular factors have been studied in order to refine prognosis. Colon cancers without Caudal-type homeobox transcription factor 2 (CDX2) overexpression are often associated with aggressive features such as advanced stage, poor differentiation, vascular invasion, BRAF mutation, and the CpG island methylator phenotype (78-81). Recently, Dalerba et al showed that a lack of CDX2 expression (4.1 to $6.9 \%$ of colon cancers) was associated with worse outcome in stage II and III colon cancer (HR for disease recurrence 3.44, 95\% Cl 1.60-7.38, P $=0.002$ ) (82). In stage III colon cancer, adjuvant treatment was beneficial in both CDX2-positive and negative tumors, but CDX2 seemed to be predictive of benefit in stage II patients (82). Though very promising, these findings on the prognostic and predictive value of CDX2 need to be confirmed in external series based on patients enrolled in clinical trials, in order to increase the quality of clinical data and the robustness of this marker before using it in daily practice.

We can also highlight the PI3KCA mutations that are present in approximately 10 to $20 \%$ of colon cancers. They seem to be associated with the benefit of aspirin as adjuvant treatment $(83,84) . \mathrm{Ng}$ et al showed that patients with stage III colon cancer treated with aspirin showed a trend to better DFS and OS $(\mathrm{HR} 0.61,95 \% \mathrm{Cl}=$ 
0.36 to 1.04 ; and $0.48,95 \% \mathrm{Cl}=0.23$ to 0.99 , respectively) (84). However, prospective studies still need to be conducted to validate these results.

Finally, with the breakthrough of liquid biopsy, circulating tumor DNA (ctDNA) has been assessed in early stage colon cancer (85-87). Its very high prognostic value for OS and RFS has been shown in very small cohorts $(86,87)$ To date, no study has assessed the prognostic value of ctDNA in stage III colon cancer, but 3 studies are ongoing (NCT03416478, NCT02842203, NCT03312374).

All these findings underline the need for an integrative approach, which would include clinical, pathological, biological and molecular features, in order to define prognosis better and to find predictive markers of the benefit of adjuvant chemotherapy in daily practice.

\section{Perspective in the future management of nonmetastatic colon cancer}

Colon cancer is heterogeneous and at least 4 entities are already characterized at the genomic level to define colon carcinogenesis : microsatellite instability, chromosomal instability, hypermethylated colon cancers and hypermutated colon cancers (Figure 2). On the top of these 4 entities several mutational profiles may be of interest to better treat our patients including MMR, PI3K, BRAF, HER-2, mutation in DNA polymerase (PoID/PolE) and RAS.

MMR, BRAF and RAS status are nowadays usually determined in colon cancer patients in the metastatic setting. Moreover, targeting HER2 in HER2+ metastatic colon cancer patients recently gave promising results. Some of these advances may translate in new trials the adjuvant setting.

Recently, immunotherapy was shown to be effective in dMMR/MSI metastatic tumors (88). In the adjuvant setting, immunotherapy has already proven effective, particularly in melanoma (89), and one study is currently ongoing in the adjuvant setting for dMMR/MSI colon cancer, Table 3 (NCT02912559). 
Along the same lines, progress made in the metastatic setting for HER2 mutated or amplified colon cancer has been assessed in the localized setting (90). For unresectable colon cancer, including non metastatic locally advanced patients, a trial is currently assessing dual HER2 inhibition (pertuzumab plus trastuzumab) compared with chemotherapy (NCT03365882). Adjuvant project for R0 resected non metastatic colon cancer are currently discussed.

PI3KCA mutated colon cancer patients are another molecular subgroup of patients currently under study. Mutations in the PI3KCA signaling pathways are present in approximately $15-20 \%$ of colon cancer. In the metastatic setting, PI3KCA mutations seem to confer resistance to anti-EGFR treatment (in RAS wild type patients). Recently, evidence of the potential benefit of aspirin on colon cancer specific mortality in PI3KCA mutated colon cancer was observed (83). Thus, the PRODIGE 50-ASPIK trial (NCT02467582) is testing aspirin adjuvant treatment in PI3KCA mutated stage III or high-risk stage II patients, and the JCOG1503C trial (UMIN000031532) regardless of the PI3KCA mutation.

Better use of the usual chemotherapy drugs may also improve management of nonmetastatic colon cancer, and trials are exploring the intensification of adjuvant treatment for high-risk stage III colon cancer (IROCAS, NCT02967289) and treatment de-escalation in elderly patients (ACE NCT02978612, and PRODIGE 34ADAGE NCT02355379). As described above, the perioperative regimen is also a potential source of improvement for the management of non metastatic colon cancer. In the FOxTROT trial, perioperative chemotherapy was shown to be feasible, with an increase of $16 \%$ in $\mathrm{R} 0$ resections and no increase in post-surgery complications (50).

Finally, the very high prognostic value of ctDNA for OS and RFS was showed in very small cohorts. Indeed, Tie et al, showed in 230 patients with stage II colon cancer that ctDNA was detectable in $7.9 \%$ of patients without adjuvant chemotherapy and $11 \%$ of patients with adjuvant chemotherapy (87). In this study, ctDNA postoperative detection was associated with worse RFS in treated and untreated patients (multivariate HR: 7.5 95\% $\mathrm{Cl}: 2.6-22$ and HR: 3.3 95\% Cl:1.6-7.0, respectively) (87). Moreover, patients who had postoperative positive ctDNA but post-adjuvant chemotherapy negative ctDNA seemed to have better outcome. Those impressive results have led to the development of studies assessing the prognostic 
value of ctDNA in stage II and III colon cancer (NCT02842203, NCT03312374, NCT03637686), and other studies are going to explore the value of ctDNA-driven adjuvant treatment in stage II and III colon cancer.

Table 3 summarizes the main studies designed to improve adjuvant treatment for specific subgroups of colon cancer. 


\section{Conclusion}

The landscape of adjuvant treatment for colon cancer is still moving. It is clear that no treatment is needed for stage I and dMMR/MSI II colon cancer. For pMMR stage II colon cancer, with its consensual poor prognostic features ( $T 4$, perforation and less than 12 nodes examined), adjuvant treatment with fluoropyrimidines is recommended, the lack of a clear overall survival benefit when oxaliplatin is added makes FOLFOX an option in many guidelines. For stage III colon cancer, adjuvant treatment with fluoropyrimidines and oxaliplatin is recommended: 3 months of treatment for low-risk stage III (T3N1) and 6 months for high-risk stage III colon cancer (T4 and/or N2). No strong predictive factor has been identified to date. Patients with specific druggable molecular targets may benefit from targeted agents. Ongoing trials are mainly dedicated to rare subgroups that may benefit from a specific treatment (dMMR, HER2+, PI3KCA mutated, BRAF mutated), new treatment settings (peri-operative FOLFOX), treatment with chemotherapeutic agents of specific patient subgroups (elderly patients, high risk stage III) and treatment guidance by ctDNA.

\section{TABLES}

Table1: Results of the main studies in adjuvant colon cancer

\begin{tabular}{|c|c|c|c|c|c|c|c|}
\hline Study & Year of publication & Phase & $\begin{array}{l}\text { Sta } \\
\text { ge }\end{array}$ & $\begin{array}{l}\text { Contr } \\
\text { ol } \\
\text { arm }\end{array}$ & Exp arm & $\begin{array}{l}\text { DFS } \\
\text { contr } \\
\text { ol/ex } \\
\mathrm{p}\end{array}$ & $\begin{array}{l}\text { OS } \\
\text { contr } \\
\text { ol/ex } \\
\mathrm{p}\end{array}$ \\
\hline $\begin{array}{l}\text { IMPACT } \\
\text { B2 }\end{array}$ & $\begin{array}{lll}\begin{array}{l}\text { Lancet Lond Engl } \\
1995\end{array} & & \\
\end{array}$ & $\begin{array}{l}\text { Meta- } \\
\text { analys } \\
\text { is }\end{array}$ & II & $\begin{array}{l}\text { No } \\
\text { chem } \\
\text { other } \\
\text { apy } \\
\text { (n= } \\
? \text { ) }\end{array}$ & $\begin{array}{l}\text { Adjuvant } \\
\text { chemoth } \\
\text { erapy } \\
(n=1016)\end{array}$ & $\begin{array}{l}5 y \\
\text { event } \\
\text {-free } \\
\text { survi } \\
\text { val } \\
73 \% / \\
76 \% \\
\text { (HR: } \\
0.83 \text {, } \\
90 \% \\
\mathrm{Cl} \text { : } \\
0.72- \\
1.07)\end{array}$ & $\begin{array}{l}5 y \\
80 \% / \\
82 \% \\
\text { (HR: } \\
0.86, \\
90 \% \\
\mathrm{Cl}: \\
0.68- \\
1.07 \\
\mathrm{p}=0 . \\
57)\end{array}$ \\
\hline $\begin{array}{l}10 y \text { results } \\
\text { NSABP }\end{array}$ & $\begin{array}{l}\text { Wolmark J Natl } \\
\text { Cancer Inst } 1988\end{array}$ & III & $\begin{array}{l}\text { Duk } \\
\text { e B }\end{array}$ & $\begin{array}{l}\text { no } \\
\text { treat }\end{array}$ & $\begin{array}{l}\text { postoper } \\
\text { ative }\end{array}$ & $\begin{array}{l}7 \% \\
\text { differ }\end{array}$ & $\begin{array}{l}10 y \\
\text { OS:H }\end{array}$ \\
\hline
\end{tabular}




\begin{tabular}{|c|c|c|c|c|c|c|c|}
\hline $\mathrm{C} 01$ & $\begin{array}{l}\text { Smith et al J Natl } \\
\text { Cancer Inst } 2004\end{array}$ & & C & $\begin{array}{l}\text { ment } \\
(n=3 \\
94) ;\end{array}$ & $\begin{array}{l}\text { chemoth } \\
\text { erapy (5- } \\
\text { FU/semu } \\
\text { stine/vinc } \\
\text { ristine } \\
\text { ( } \mathrm{n}=379) ; \\
\text { or } \\
\text { postoper } \\
\text { ative } \\
\text { BCG } \\
(n=393)\end{array}$ & $\begin{array}{l}\text { ence } \\
\text { in } \\
\text { terms } \\
\text { of } \\
\text { DFS } \\
\text { at } 5 y \\
10 y \\
\text { DFS: } \\
\text { MOF } \\
\text { vs } \\
\text { surge } \\
\text { ry } \\
\text { HR:0 } \\
.88 \\
(0.72 \\
\text { to } \\
1.07) \\
\text { P } \\
.19\end{array}$ & $\begin{array}{l}\mathrm{R} \\
0.89 \\
(0.72 \\
\text { to } \\
1.09) \\
\mathrm{P}= \\
0.24\end{array}$ \\
\hline $\begin{array}{l}\text { NSABP } \\
\text { C02 }\end{array}$ & $\begin{array}{lll}\text { Wolmark } & \mathrm{J} & \text { Clin } \\
\text { Oncol 1990 } & & \\
\end{array}$ & III & $\begin{array}{l}\text { Duk } \\
\text { e A } \\
\text { b C }\end{array}$ & $\begin{array}{l}\text { surg } \\
\text { ery } \\
\text { alone } \\
(n=5 \\
81)\end{array}$ & $\begin{array}{l}\text { periopera } \\
\text { tive portal } \\
\text { venous } \\
\text { infusion } \\
5 F U \\
(n=577)\end{array}$ & $\begin{array}{l}5 y \\
60 \% / \\
69 \% \\
p=0.0 \\
2\end{array}$ & $\begin{array}{l}5 y \\
70 \% / \\
78 \% \\
p=0.0 \\
7\end{array}$ \\
\hline $\begin{array}{l}\text { NSABP } \\
\mathrm{C} 03\end{array}$ & $\begin{array}{l}\text { Wolmark J Clin Oncol } \\
1993\end{array}$ & & $\begin{array}{l}\text { II } \\
\text { and } \\
\text { III }\end{array}$ & $\begin{array}{l}\text { MOF } \\
(n=5 \\
42)\end{array}$ & $\begin{array}{l}5 \mathrm{FU} / \mathrm{LV} \\
(\mathrm{n}=539)\end{array}$ & $\begin{array}{l}5 y \\
54 \% / \\
66 \% \\
p=0.0 \\
004\end{array}$ & $\begin{array}{l}5 y \\
66 \% / \\
76 \% \\
p=.00 \\
3\end{array}$ \\
\hline QUASAR & $\begin{array}{ll}\text { QUASAR } & \\
\text { collaborative } & \text { group } \\
\text { Lancet 2007 }\end{array}$ & & I-III & $\begin{array}{l}\text { surg } \\
\text { ery } \\
\text { alone } \\
(n=1 \\
617)\end{array}$ & $\begin{array}{l}\text { Chemoth } \\
\text { erapy } \\
(n=1622)\end{array}$ & $\begin{array}{l}\text { RR } \\
\text { for } \\
\text { recur } \\
\text { rence } \\
0.78 \\
(95 \% \\
\mathrm{Cl} \\
0.67 \\
- \\
0.91 ; \\
\mathrm{p}=0 . \\
001\end{array}$ & $\begin{array}{l}\text { RR } \\
\text { (che } \\
\text { moth } \\
\text { erapy } \\
\text { vs } \\
\text { surge } \\
\text { ry) } \\
0.82 \\
(95 \% \\
\text { Cl } \\
0.70- \\
0.95 ; \\
p=0.0 \\
08\end{array}$ \\
\hline MOSAIC & $\begin{array}{l}\text { André et al } \mathrm{J} \text { Clin } \\
\text { Oncol 2015 }\end{array}$ & III & $\begin{array}{l}\text { II } \\
\text { and } \\
\text { III }\end{array}$ & $\begin{array}{l}\text { LV5F } \\
\text { U2 } \\
\text { (112 } \\
3)\end{array}$ & $\begin{array}{l}\text { FOLFOX } \\
4 \\
(n=1123)\end{array}$ & $\begin{array}{l}10 y \\
61.7 \\
\% / 67 \\
.5 \% \\
\text { HR } \\
0.82 \\
\end{array}$ & $\begin{array}{l}10 y \\
67.1 \\
\% / 71 . \\
7 \% \\
\text { HR } \\
0.85 \\
\end{array}$ \\
\hline
\end{tabular}




\begin{tabular}{|c|c|c|c|c|c|c|c|}
\hline & & & & & & $\begin{array}{l}(0.71 \\
- \\
0.95) \\
p=.00 \\
7\end{array}$ & $\begin{array}{l}(0.73- \\
0.99) ; \\
P \\
.043\end{array}$ \\
\hline $\begin{array}{l}\text { NSABP } \\
\text { C07 }\end{array}$ & $\begin{array}{l}\text { Kuebler J Clin Oncol } \\
\text { 2007/Yothers J Clin } \\
\text { Oncol } 2011\end{array}$ & III & $\begin{array}{l}\text { II } \\
\text { and } \\
\text { III }\end{array}$ & $\begin{array}{l}5 F U / \\
L V \\
(n=1 \\
245)\end{array}$ & $\begin{array}{l}\text { 5FU/LV- } \\
\text { oxali } \\
(n=1247)\end{array}$ & $\begin{array}{l}5 y \\
64.2 \\
\% / 69 . \\
4 \% \\
\text { FLOX } \\
\text { vs } \\
\text { FULV } \\
: \quad H R \\
\text { DFS } \\
0.82 \\
(0.72- \\
0.93) \\
0 p=0 . \\
02\end{array}$ & $\begin{array}{l}5 y \\
78.8 \\
\% / 81 . \\
8 \%\end{array}$ \\
\hline $\begin{array}{l}\text { XELOXA/ } \\
\text { Schmoll/N } \\
\text { O16968 }\end{array}$ & $\begin{array}{lll}\text { Schmoll } & \mathrm{J} & \text { Clin } \\
\text { Oncol 2015 } & & \end{array}$ & III & III & $\begin{array}{l}\mathrm{FU} / \mathrm{F} \\
\mathrm{A}, \\
(\mathrm{n}=9 \\
42)\end{array}$ & $\begin{array}{l}\text { CAPOX, } \\
\text { (n 944) }\end{array}$ & $\begin{array}{l}7 y \\
56 \% / \\
63 \% \\
\text { HR } \\
\text { (exp } \\
\text { vs } \\
\text { contr } \\
\text { ol) } \\
0.80 ; \\
95 \% \\
\text { Cl, } \\
0.69 \\
\text { to } \\
0.93 ; \\
P \\
.004\end{array}$ & $\begin{array}{l}7 y \\
67 \% / 7 \\
3 \% \\
\text { HR } \\
\text { (exp } \\
\text { vs } \\
\text { contro } \\
\text { l), } \\
0.83 ; \\
95 \% \\
\mathrm{Cl}, \\
0.70 \\
\text { to } \\
0.99 ; \\
P .04\end{array}$ \\
\hline $\begin{array}{l}\text { NSABP } \\
\text { C08 }\end{array}$ & $\begin{array}{l}\text { Allegra J Clin Oncol } \\
2011\end{array}$ & III & $\begin{array}{l}\text { II } \\
\text { and } \\
\text { III }\end{array}$ & $\begin{array}{l}\text { FOL } \\
\text { FOX } \\
6 \\
(n=1 \\
356)\end{array}$ & $\begin{array}{l}\text { FOLFOX } \\
6+\text { bevaci } \\
\text { zumab } \\
(n=1354)\end{array}$ & $\begin{array}{l}3 y \\
75.5 \\
\% / 77 . \\
4 \% \\
\text { HR } \\
\text { (exp } \\
\text { vs } \\
\text { contr } \\
\text { ol), } \\
0.89 ; \\
95 \% \\
\mathrm{Cl} \text {, } \\
0.76 \\
\text { to } \\
1.04 ; \\
\mathrm{P} \\
.15 / /\end{array}$ & I \\
\hline AVANT & $\begin{array}{l}\text { De Gramont Lancet } \\
\text { Oncol } 2012\end{array}$ & III & III & $\begin{array}{l}\text { FOL } \\
\text { FOX }\end{array}$ & $\begin{array}{l}\text { FOLFOX } \\
\text { or CAPOX }\end{array}$ & $\begin{array}{l}\mathrm{HR} \\
\text { for }\end{array}$ & $\begin{array}{l}\text { HR } \\
\text { for }\end{array}$ \\
\hline
\end{tabular}




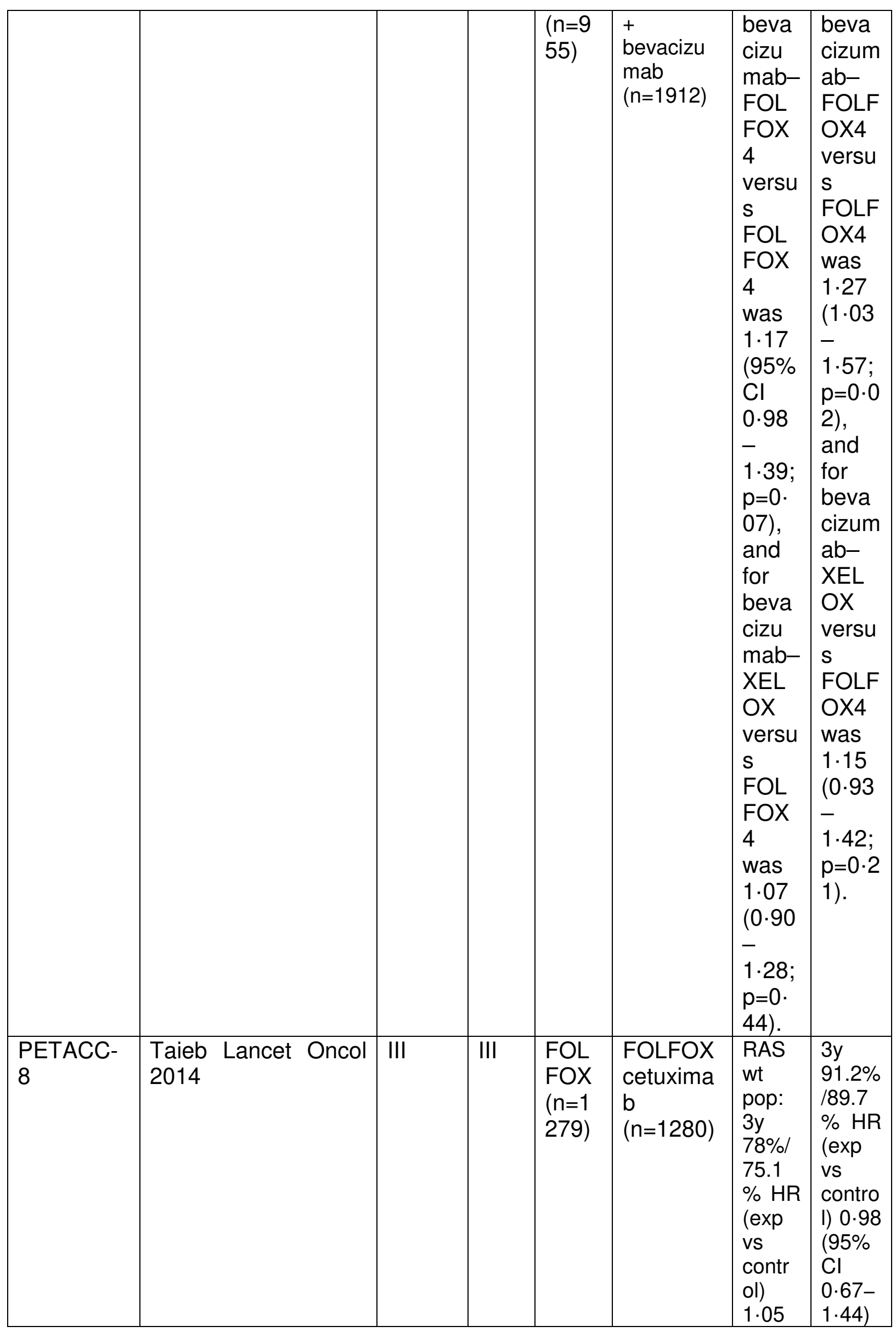




\begin{tabular}{|c|c|c|c|c|c|c|c|}
\hline & & & & & & $\begin{array}{l}(95 \% \\
\mathrm{Cl} \\
0 \cdot 85- \\
1 \cdot 29\end{array}$ & \\
\hline $\begin{array}{l}\text { NCCTG } \\
\text { NO147 }\end{array}$ & Alberts JAMA 2012 & III & III & $\begin{array}{l}\text { FOL } \\
\text { FOX } \\
6 \\
(n=1 \\
337)\end{array}$ & $\begin{array}{l}\text { FOLFOX } \\
6 \\
\text { cetuxima } \\
b \\
(n=1349)\end{array}$ & $\begin{array}{l}\text { KRAS } \\
\text { wt: } \\
3 y \\
74.6 \\
\% / 71 . \\
5 \% \\
\text { HR } \\
\text { (exp } \\
\text { vs } \\
\text { contr } \\
\text { ol), } \\
1.21 \text {; } \\
95 \% \\
\text { Cl, } \\
0.98- \\
1.49 ; \\
\text { P=.08 }\end{array}$ & $\begin{array}{l}3 y \\
87.3 \% \\
185.6 \\
\% \text { HR } \\
\text { (exp } \\
\text { vs } \\
\text { contro } \\
\text { l) } 1.25 \\
\text { (0.92- } \\
1.68) \\
\text { p }=0.1 \\
5\end{array}$ \\
\hline $\begin{array}{l}\text { PETACC- } \\
3\end{array}$ & $\begin{array}{l}\text { Van Cutsem J Clin } \\
\text { Oncol } 2009\end{array}$ & III & III & $\begin{array}{l}\text { LV5F } \\
\text { U2 } \\
(114 \\
9)\end{array}$ & $\begin{array}{l}\text { FOLFIRI } \\
(n=1149)\end{array}$ & $\begin{array}{l}5 y \\
54.3 \\
\% / 56 \\
.7 \% \\
p=0.1 \\
06\end{array}$ & $\begin{array}{l}5 y \\
71.3 \\
\% / 73 . \\
6 \% \\
p=0.0 \\
94\end{array}$ \\
\hline
\end{tabular}

Abbreviations: DFS: disease-free survival, OS: overall survival; Exp arm: experimental arm; $3 y$, $5 y, 7 y, 10 y:$ three years, five years, seven years, ten years; HR: hazard ratio, RR: relative risk; Treatments: MOF: semustine + vincristine + 5 fluorouracil 5FU/LV or LV5FU2 or FU/FA: 5 fluorouracil + leucovorin, FOLFOX: LV5FU2 + oxaliplatin, CAPOX: capecitabine + oxaliplatin, FOLFIRI: LV5FU2 + irinotecan 
Table 2: Summary of 3-year DFS rates according to treatment arm and risk group from the IDEA study (Grothey et al, N Engl J Med, 2018)

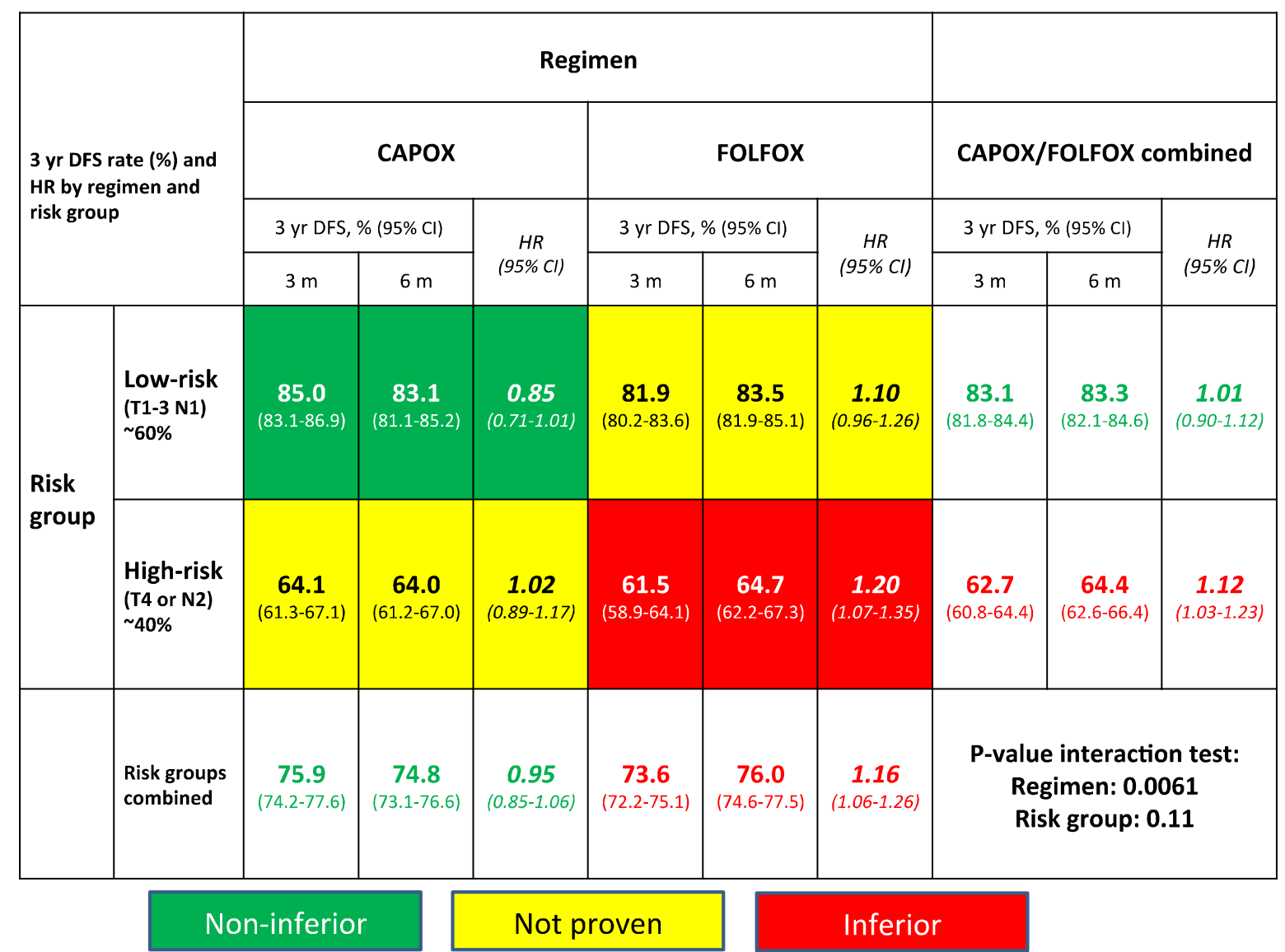

Abbreviations: 3 yr: three years; DFS: disease-free survival; CAPOX: capecitabine + oxaliplatin; FOLFOX: 5 fluorouracil + oxaliplatin

Table 3: Ongoing studies in adjuvant colon cancer

\begin{tabular}{|c|c|c|c|c|c|c|}
\hline & $\begin{array}{l}\text { Trial } \\
\text { number }\end{array}$ & $\begin{array}{l}\text { Type of } \\
\text { study }\end{array}$ & Title & Acronym & Treatment & $\begin{array}{ll}\begin{array}{l}\text { Population } \\
\text { characteristics) }\end{array} & \text { (number, } \\
\end{array}$ \\
\hline $\begin{array}{c}\text { Molecu } \\
\text { lar- } \\
\text { driven } \\
\text { trials }\end{array}$ & $\begin{array}{l}\text { NCT0291 } \\
2559\end{array}$ & phase III & $\begin{array}{l}\text { Combinatio } \\
n \\
\text { Chemothera } \\
\text { py With or } \\
\text { Without } \\
\text { Atezolizuma } \\
\mathrm{b} \text { in } \\
\text { Treating } \\
\text { Patients } \\
\text { With Stage } \\
\text { III Colon } \\
\text { Cancer and } \\
\text { Deficient } \\
\text { DNA } \\
\text { Mismatch }\end{array}$ & $\begin{array}{l}\text { ATOMIC Alliance } \\
\text { A021502 }\end{array}$ & $\begin{array}{l}\text { mFOLFOX6 } \\
+/- \\
\text { atezolizuma } \\
\text { b }\end{array}$ & $\begin{array}{l}700 \text { patients with dMMR } \\
\text { colon cancer }\end{array}$ \\
\hline
\end{tabular}




\begin{tabular}{|c|c|c|c|c|c|c|}
\hline & & & Repair & & & \\
\hline & $\begin{array}{l}\text { NCT0246 } \\
6906\end{array}$ & phase II & $\begin{array}{l}\text { RhGM-CSF } \\
\text { as Adjuvant } \\
\text { Immunother } \\
\text { apy in } \\
\text { Treating } \\
\text { Stage III } \\
\text { Colon } \\
\text { Cancer }\end{array}$ & & $\begin{array}{l}\text { RhGM-CSF } \\
\text { vs placebo }\end{array}$ & 60 stage III \\
\hline & $\begin{array}{l}\text { NCT0246 } \\
7582\end{array}$ & phase III & $\begin{array}{l}\text { Adjuvant } \\
\text { Aspirin } \\
\text { Treatment } \\
\text { for Colon } \\
\text { Cancer } \\
\text { Patients }\end{array}$ & $\begin{array}{l}\text { ASPIK } \\
\text { PRODIGE } 50\end{array}$ & $\begin{array}{l}\text { aspirin } \\
\text { versus } \\
\text { placebo }\end{array}$ & $\begin{array}{l}185 \text { patients with stage III } \\
\text { or high-risk stage II colon } \\
\text { cancer harboring PI3KCA } \\
\text { mutation }\end{array}$ \\
\hline \multirow[t]{4}{*}{$\begin{array}{l}\text { Clinical } \\
\text { and } \\
\text { age- } \\
\text { driven } \\
\text { trials }\end{array}$} & $\begin{array}{l}\text { NCT0296 } \\
7289\end{array}$ & phase III & $\begin{array}{l}\text { IRinotecan } \\
\text { and } \\
\text { Oxaliplatin } \\
\text { for Colon } \\
\text { Cancer in } \\
\text { Adjuvant } \\
\text { Setting }\end{array}$ & IROCAS & $\begin{array}{l}\text { FOLFOX } \\
\text { versus } \\
\text { FOLFIRINO } \\
X\end{array}$ & $\begin{array}{l}640 \text { high-risk stage III } \\
\text { colon cancer (pT4 and/or } \\
\text { N2) }\end{array}$ \\
\hline & $\begin{array}{l}\text { NCT0297 } \\
8612\end{array}$ & phase II & $\begin{array}{l}\text { Adjuvant } \\
\text { Chemothera } \\
\text { py In Elderly } \\
\text { With Colon } \\
\text { Cancer } \\
\text { Stage III }\end{array}$ & ACE & $\begin{array}{l}\text { Capecitabin } \\
\text { e }\end{array}$ & $\begin{array}{l}170 \text { patients with stage III } \\
\text { colon cancer and older } \\
\text { than } 75 \text { years }\end{array}$ \\
\hline & $\begin{array}{l}\text { NCT0235 } \\
5379\end{array}$ & phase III & $\begin{array}{l}\text { Randomize } \\
\text { d Study } \\
\text { Evaluating } \\
\text { Adjuvant } \\
\text { Chemothera } \\
\text { py After } \\
\text { Resection } \\
\text { of Stage III } \\
\text { Colonic } \\
\text { Adenocarci } \\
\text { noma in } \\
\text { Patients of } \\
70 \text { and Over } \\
\text { (ADAGE) }\end{array}$ & $\begin{array}{ll}\text { PRODIGE } & 34 \\
\text { ADAGE }\end{array}$ & $\begin{array}{l}\text { capecitabin } \\
\text { e or 5FU, } \\
\text { CAPOX or } \\
\text { FOLFOX, } \\
\text { observation }\end{array}$ & $\begin{array}{l}774 \text { patients with stage III } \\
\text { colon cancer and older } \\
\text { than } 70 \text { years }\end{array}$ \\
\hline & - & Phase III & $\begin{array}{l}\text { Adjuvant } \\
\text { chemotherap } \\
\text { y for colon } \\
\text { cancer with } \\
\text { high } \\
\text { evidence in } \\
\text { high risk } \\
\text { stage }\end{array}$ & $\begin{array}{l}\text { JFMC48-1301-C4 } \\
\text { ACHIEVE-2 (UMIN } \\
\text { trial 000013036) }\end{array}$ & $\begin{array}{l}\text { mFOLFOX6 } \\
\text { or XELOX for } \\
3 \text { months as } \\
\text { adjuvant } \\
\text { chemotherap } \\
\text { y compared } \\
\text { to } 6 \text { months } \\
\text { mFOLFOX6/X } \\
\text { ELOX in } \\
\text { terms of DFS } \\
\text { for high -risk } \\
\text { stage II colon } \\
\text { cancer }\end{array}$ & $\begin{array}{l}\text { High risk stage II colon } \\
\text { cancer }\end{array}$ \\
\hline $\begin{array}{l}\text { ctDNA- } \\
\text { driven } \\
\text { trials }\end{array}$ & $\begin{array}{l}\text { NCT0284 } \\
2203\end{array}$ & $\begin{array}{l}\text { observati } \\
\text { onal }\end{array}$ & $\begin{array}{l}\text { Use of } \\
\text { ctDNA for } \\
\text { Monitoring } \\
\text { of Stage III } \\
\text { Colorectal } \\
\text { Cancer }\end{array}$ & & $\begin{array}{l}\text { evaluate } \\
\text { ctDNA as a } \\
\text { prognostic } \\
\text { marker and } \\
\text { as a monitor } \\
\text { of disease } \\
\text { recurrence }\end{array}$ & 150 stage III colon cancer \\
\hline
\end{tabular}




\begin{tabular}{|c|c|c|c|c|c|}
\hline & & & & $\begin{array}{l}\text { in stage III } \\
\text { colorectal } \\
\text { cancer }\end{array}$ & \\
\hline $\begin{array}{l}\text { NCT0331 } \\
2374\end{array}$ & $\begin{array}{l}\text { observati } \\
\text { onal }\end{array}$ & $\begin{array}{l}\text { ctDNA as a } \\
\text { Prognostic } \\
\text { Marker for } \\
\text { Postoperati } \\
\text { ve Relapse } \\
\text { in Early and } \\
\text { Intermediat } \\
\text { e Stage } \\
\text { Colorectal } \\
\text { Cancer }\end{array}$ & & $\begin{array}{l}\text { evaluate } \\
\text { circulating } \\
\text { tumor DNA } \\
\text { (ctDNA) as } \\
\text { a predictive } \\
\text { marker for } \\
\text { DFS in } \\
\text { stage II and } \\
\text { III colorectal } \\
\text { cancer }\end{array}$ & $\begin{array}{l}350 \text { patients with stage II } \\
\text { and III colon cancer }\end{array}$ \\
\hline $\begin{array}{l}\text { NCT0363 } \\
7686\end{array}$ & $\begin{array}{l}\text { observati } \\
\text { onal }\end{array}$ & $\begin{array}{l}\text { Circulating } \\
\text { Tumor DNA } \\
\text { Analysis to } \\
\text { Optimize } \\
\text { Treatment } \\
\text { for Patients } \\
\text { With } \\
\text { Colorectal } \\
\text { Cancer } \\
\text { (IMPROVE) }\end{array}$ & & $\begin{array}{l}\text { to confirm } \\
\text { that ctDNA } \\
\text { detected in } \\
\text { plasma after } \\
\text { intended } \\
\text { curative } \\
\text { treatment } \\
\text { for CRC can } \\
\text { be applied } \\
\text { in clinical } \\
\text { practice as } \\
\text { a marker of } \\
\text { subclinical } \\
\text { residual } \\
\text { disease and } \\
\text { risk of } \\
\text { recurrence. }\end{array}$ & $\begin{array}{l}1800 \text { stage I to III colon } \\
\text { cancer }\end{array}$ \\
\hline- & & $\begin{array}{l}\text { ctDNA } \\
\text { analysis } \\
\text { informing } \\
\text { adjuvant } \\
\text { chemotherap } \\
y \text { in stage II } \\
\text { colon cancer }\end{array}$ & $\begin{array}{l}\text { DYNAMIC } \\
\text { (ACTRN126150003 } \\
81583 \text { ) }\end{array}$ & $\begin{array}{l}\text { To evaluate } \\
\text { the use of } \\
\text { ctDNA to } \\
\text { guide } \\
\text { adjuvant } \\
\text { chemotherap } \\
\text { y on RFS }\end{array}$ & $\begin{array}{l}\text { Stage II colon or rectal } \\
\text { cancer }\end{array}$ \\
\hline- & $\begin{array}{l}\text { Phase } \\
\text { II/III }\end{array}$ & $\begin{array}{l}\text { Tumour DNA } \\
\text { analysis } \\
\text { informing } \\
\text { adjuvant } \\
\text { chemotherap } \\
\text { y in stage III } \\
\text { colon cancer: } \\
\text { a multicenter } \\
\text { phase II/III } \\
\text { randomized } \\
\text { controlled } \\
\text { study } \\
\text { (DYNAMIC- } \\
\text { III) }\end{array}$ & $\begin{array}{l}\text { DYNAMIC III } \\
\text { (ACTRN126170015 } \\
66325)\end{array}$ & $\begin{array}{l}\text { To compare } \\
\text { treatment } \\
\text { informed by } \\
\text { ctDNA } \\
\text { results to } \\
\text { standard } \\
\text { care in } \\
\text { patients with } \\
\text { stage III } \\
\text { colon cancer }\end{array}$ & Stage III colon cancer \\
\hline- & Phase III & & $\begin{array}{lc}\text { CIRCULATE } & \text { France } \\
\text { (EudraCT } & \text { 2019- } \\
000935-15) & \end{array}$ & $\begin{array}{l}\text { To compare } \\
\text { FOLFOX } \\
\text { versus } \\
\text { observation } \\
\text { in ctDNA } \\
\text { positive }\end{array}$ & Stage II colon cancer \\
\hline
\end{tabular}




\begin{tabular}{|l|l|l|l|l|l|}
\hline & - & & $\begin{array}{l}\text { CIRCULATE } \\
\text { Germany }\end{array}$ & $\begin{array}{l}\text { stage II colon } \\
\text { cancer } \\
\text { patients after } \\
\text { RO resection }\end{array}$ & \\
& & & & & \\
& & & & & \\
\hline
\end{tabular}

FOLFOX: 5 fluorouracil + oxaliplatin, RhGM-CSF: recombinant human granulocyte-macrophage colonystimulating factor, FOLFIRINOX: 5 fluorouracil + oxaliplatin + irinotecan, CAPOX: capecitabine + oxaliplatin dMMR: deficient mismatch repair, ctDNA: circulating tumor DNA 


\section{FIGURES}

Figure 1: Survival rates and paradigm in stage III colon cancer $100 \%$ receiving adjuvant chemotherapy

$50 \%$ cured with surgery alone

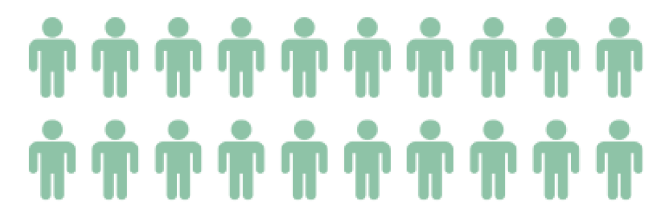

光 光

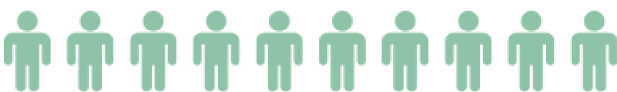

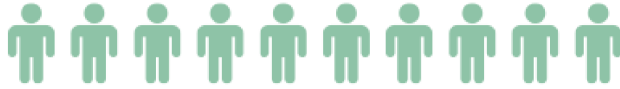

$20 \%$ cured with adjuvant

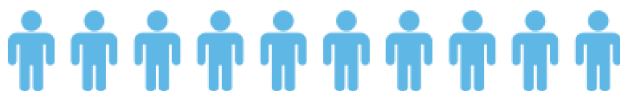

chemotherapy

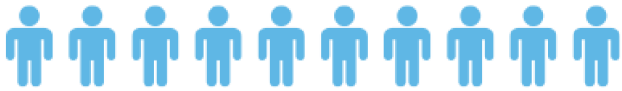

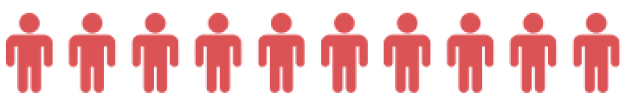

$30 \%$ recurrences

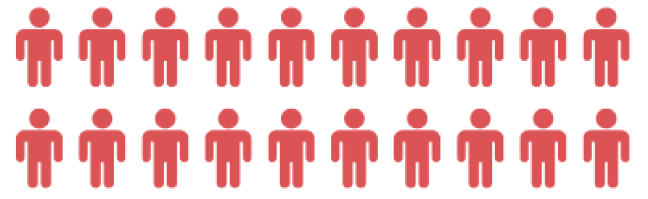


Figure 2: Colon cancer diversity. Colon cancer is composed of multiple subtypes that may be differently treated in the future in the adjuvant setting.

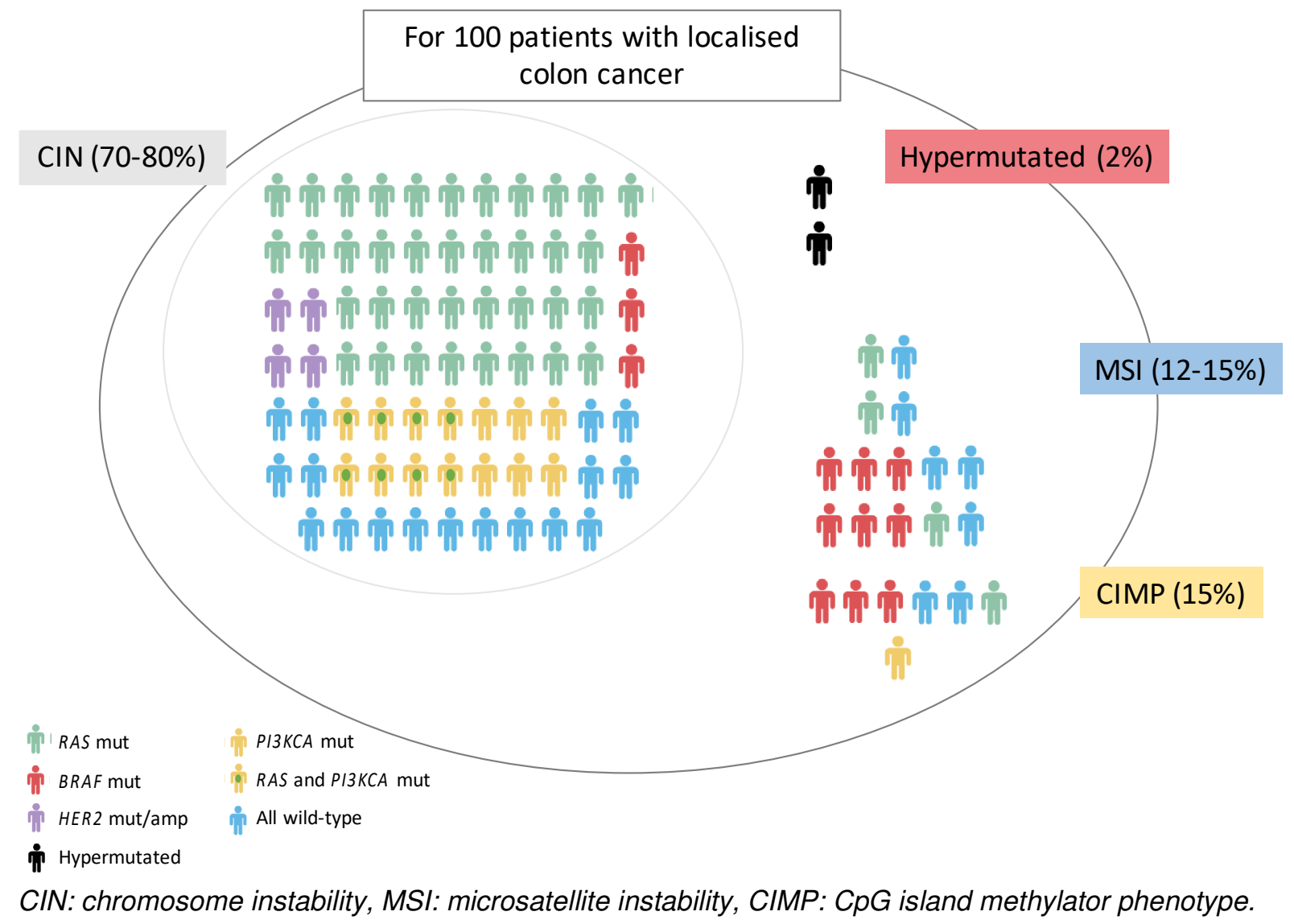




\section{REFERENCES:}

1. Stewart BW, Wild CP. World Cancer Report 2014. Lyon: International Agency for Research on Cancer/World Health Organization; 2014.

2. Lecomte T, André T, Panis Y, Laurent-Puig P, Bibeau F, Taieb J. Cancer du Colon. In: Thésaurus National de Cancérologie Digestive [Internet]. 2018. Available from: http://www.tncd.org

3. Van Cutsem E, Cervantes A, Adam R, Sobrero A, Van Krieken JH, Aderka D, et al. ESMO consensus guidelines for the management of patients with metastatic colorectal cancer. Ann Oncol Off J Eur Soc Med Oncol ESMO. 2016 Aug;27(8):1386-422.

4. Gunderson LL, Jessup JM, Sargent DJ, Greene FL, Stewart AK. Revised TN categorization for colon cancer based on national survival outcomes data. J Clin Oncol Off J Am Soc Clin Oncol. 2010 Jan 10;28(2):264-71.

5. Quasar Collaborative Group, Gray R, Barnwell J, McConkey C, Hills RK, Williams NS, et al. Adjuvant chemotherapy versus observation in patients with colorectal cancer: a randomised study. Lancet. 2007 Dec 15;370(9604):2020-9.

6. Efficacy of adjuvant fluorouracil and folinic acid in colon cancer. International Multicentre Pooled Analysis of Colon Cancer Trials (IMPACT) investigators. Lancet Lond Engl. 1995 Apr 15;345(8955):939-44.

7. Smith RE, Colangelo L, Wieand HS, Begovic M, Wolmark N. Randomized trial of adjuvant therapy in colon carcinoma: 10-year results of NSABP protocol C-01. J Natl Cancer Inst. 2004 Aug 4;96(15):1128-32.

8. Wolmark N, Colangelo L, Wieand S. National Surgical Adjuvant Breast and Bowel Project trials in colon cancer. Semin Oncol. 2001 Feb;28(1 Suppl 1):9-13.

9. Wolmark N, Rockette H, Wickerham DL, Fisher B, Redmond C, Fisher ER, et al. Adjuvant therapy of Dukes' A, B, and C adenocarcinoma of the colon with portal-vein fluorouracil hepatic infusion: preliminary results of National Surgical Adjuvant Breast and Bowel Project Protocol C-02. J Clin Oncol Off J Am Soc Clin Oncol. 1990 Sep;8(9):1466-75. 10. André T, Boni C, Mounedji-Boudiaf L, Navarro M, Tabernero J, Hickish T, et al. Oxaliplatin, fluorouracil, and leucovorin as adjuvant treatment for colon cancer. $\mathrm{N}$ Engl $\mathrm{J}$ Med. 2004 Jun 3;350(23):2343-51.

11. André T, de Gramont A, Vernerey D, Chibaudel B, Bonnetain F, Tijeras-Raballand A, et al. Adjuvant Fluorouracil, Leucovorin, and Oxaliplatin in Stage II to III Colon Cancer: Updated 10-Year Survival and Outcomes According to BRAF Mutation and Mismatch Repair Status of the MOSAIC Study. J Clin Oncol Off J Am Soc Clin Oncol. 2015 Dec 10;33(35):4176-87.

12. Ribic CM, Sargent DJ, Moore MJ, Thibodeau SN, French AJ, Goldberg RM, et al. Tumor microsatellite-instability status as a predictor of benefit from fluorouracil-based adjuvant chemotherapy for colon cancer. N Engl J Med. 2003 Jul 17;349(3):247-57.

13. Moertel CG, Fleming TR, Macdonald JS, Haller DG, Laurie JA, Goodman PJ, et al. Levamisole and fluorouracil for adjuvant therapy of resected colon carcinoma. N Engl J Med. 1990 Feb 8;322(6):352-8.

14. Zaniboni A, Labianca R, Marsoni S, Torri V, Mosconi P, Grilli R, et al. GIVIO-SITAC 01: A randomized trial of adjuvant 5-fluorouracil and folinic acid administered to patients with colon carcinoma--long term results and evaluation of the indicators of health-related quality of life. Gruppo Italiano Valutazione Interventi in Oncologia. Studio Italiano Terapia Adiuvante Colon. Cancer. 1998 Jun 1;82(11):2135-44.

15. André T, Quinaux E, Louvet C, Colin P, Gamelin E, Bouche O, et al. Phase III study comparing a semimonthly with a monthly regimen of fluorouracil and leucovorin as adjuvant treatment for stage II and III colon cancer patients: final results of GERCOR C96.1. J Clin Oncol Off J Am Soc Clin Oncol. 2007 Aug 20;25(24):3732-8.

16. Köhne C-H, Bedenne L, Carrato A, Bouché O, Popov I, Gaspà L, et al. A randomised phase III intergroup trial comparing high-dose infusional 5-fluorouracil with or without folinic acid with standard bolus 5-fluorouracil/folinic acid in the adjuvant treatment of stage III colon cancer: the Pan-European Trial in Adjuvant Colon Cancer 2 study. Eur J Cancer Oxf Engl 
1990. 2013 May;49(8):1868-75.

17. Twelves C, Wong A, Nowacki MP, Abt M, Burris H, Carrato A, et al. Capecitabine as adjuvant treatment for stage III colon cancer. N Engl J Med. 2005 Jun 30;352(26):2696-704.

18. Scheithauer W, McKendrick J, Begbie S, Borner M, Burns WI, Burris HA, et al. Oral capecitabine as an alternative to i.v. 5-fluorouracil-based adjuvant therapy for colon cancer: safety results of a randomized, phase III trial. Ann Oncol Off J Eur Soc Med Oncol. 2003 Dec;14(12):1735-43.

19. Hamaguchi T, Shirao K, Moriya Y, Yoshida S, Kodaira S, Ohashi Y, et al. Final results of randomized trials by the National Surgical Adjuvant Study of Colorectal Cancer (NSASCC). Cancer Chemother Pharmacol. 2011 Mar;67(3):587-96.

20. Kato T, Ohashi Y, Nakazato H, Koike A, Saji S, Suzuki H, et al. Efficacy of oral UFT as adjuvant chemotherapy to curative resection of colorectal cancer: multicenter prospective randomized trial. Langenbecks Arch Surg. 2002 Mar;386(8):575-81.

21. Hamaguchi T, Shimada Y, Mizusawa J, Kinugasa Y, Kanemitsu Y, Ohue M, et al. Capecitabine versus S-1 as adjuvant chemotherapy for patients with stage III colorectal cancer (JCOG0910): an open-label, non-inferiority, randomised, phase 3, multicentre trial. Lancet Gastroenterol Hepatol. 2018;3(1):47-56.

22. Yothers G, O'Connell MJ, Allegra CJ, Kuebler JP, Colangelo LH, Petrelli NJ, et al. Oxaliplatin as adjuvant therapy for colon cancer: updated results of NSABP C-07 trial, including survival and subset analyses. J Clin Oncol Off J Am Soc Clin Oncol. 2011 Oct $1 ; 29(28): 3768-74$.

23. Schmoll H-J, Tabernero J, Maroun J, de Braud F, Price T, Van Cutsem E, et al. Capecitabine Plus Oxaliplatin Compared With Fluorouracil/Folinic Acid As Adjuvant Therapy for Stage III Colon Cancer: Final Results of the NO16968 Randomized Controlled Phase III Trial. J Clin Oncol Off J Am Soc Clin Oncol. 2015 Nov 10;33(32):3733-40.

24. Haller DG, Tabernero J, Maroun J, de Braud F, Price T, Van Cutsem E, et al. Capecitabine plus oxaliplatin compared with fluorouracil and folinic acid as adjuvant therapy for stage III colon cancer. J Clin Oncol Off J Am Soc Clin Oncol. 2011 Apr 10;29(11):146571.

25. Shah MA, Renfro LA, Allegra CJ, André T, de Gramont A, Schmoll H-J, et al. Impact of Patient Factors on Recurrence Risk and Time Dependency of Oxaliplatin Benefit in Patients With Colon Cancer: Analysis From Modern-Era Adjuvant Studies in the Adjuvant Colon Cancer End Points (ACCENT) Database. J Clin Oncol Off J Am Soc Clin Oncol. 2016 Mar 10;34(8):843-53.

26. Ychou M, Raoul J-L, Douillard J-Y, Gourgou-Bourgade S, Bugat R, Mineur L, et al. A phase III randomised trial of LV5FU2 + irinotecan versus LV5FU2 alone in adjuvant high-risk colon cancer (FNCLCC Accord02/FFCD9802). Ann Oncol Off J Eur Soc Med Oncol ESMO. 2009 Apr;20(4):674-80.

27. Saltz LB, Niedzwiecki D, Hollis D, Goldberg RM, Hantel A, Thomas JP, et al. Irinotecan fluorouracil plus leucovorin is not superior to fluorouracil plus leucovorin alone as adjuvant treatment for stage III colon cancer: results of CALGB 89803. J Clin Oncol Off J Am Soc Clin Oncol. 2007 Aug 10;25(23):3456-61.

28. Van Cutsem E, Labianca R, Bodoky G, Barone C, Aranda E, Nordlinger B, et al. Randomized phase III trial comparing biweekly infusional fluorouracil/leucovorin alone or with irinotecan in the adjuvant treatment of stage III colon cancer: PETACC-3. J Clin Oncol Off J Am Soc Clin Oncol. 2009 Jul 1;27(19):3117-25.

29. Allegra CJ, Yothers G, O'Connell MJ, Sharif S, Petrelli NJ, Colangelo LH, et al. Phase III trial assessing bevacizumab in stages II and III carcinoma of the colon: results of NSABP protocol C-08. J Clin Oncol Off J Am Soc Clin Oncol. 2011 Jan 1;29(1):11-6.

30. Allegra CJ, Yothers G, O'Connell MJ, Sharif S, Petrelli NJ, Lopa SH, et al. Bevacizumab in stage II-III colon cancer: 5-year update of the National Surgical Adjuvant Breast and Bowel Project C-08 trial. J Clin Oncol Off J Am Soc Clin Oncol. 2013 Jan 20;31(3):359-64.

31. de Gramont A, Van Cutsem E, Schmoll H-J, Tabernero J, Clarke S, Moore MJ, et al. Bevacizumab plus oxaliplatin-based chemotherapy as adjuvant treatment for colon cancer 
(AVANT): a phase 3 randomised controlled trial. Lancet Oncol. 2012 Dec;13(12):1225-33.

32. Alberts SR, Sargent DJ, Nair S, Mahoney MR, Mooney M, Thibodeau SN, et al. Effect of oxaliplatin, fluorouracil, and leucovorin with or without cetuximab on survival among patients with resected stage III colon cancer: a randomized trial. JAMA. $2012 \mathrm{Apr}$ 4;307(13):1383-93.

33. Taieb J, Tabernero J, Mini E, Subtil F, Folprecht G, Van Laethem J-L, et al. Oxaliplatin, fluorouracil, and leucovorin with or without cetuximab in patients with resected stage III colon cancer (PETACC-8): an open-label, randomised phase 3 trial. Lancet Oncol. $2014 \mathrm{Jul} ; 15(8): 862-73$.

34. Taieb J, Balogoun R, Le Malicot K, Tabernero J, Mini E, Folprecht G, et al. Adjuvant FOLFOX +/- cetuximab in full RAS and BRAF wildtype stage III colon cancer patients. Ann Oncol Off J Eur Soc Med Oncol. 2017 01;28(4):824-30.

35. Des Guetz G, Nicolas P, Perret G-Y, Morere J-F, Uzzan B. Does delaying adjuvant chemotherapy after curative surgery for colorectal cancer impair survival? A meta-analysis. Eur J Cancer Oxf Engl 1990. 2010 Apr;46(6):1049-55.

36. Hershman D, Hall MJ, Wang X, Jacobson JS, McBride R, Grann VR, et al. Timing of adjuvant chemotherapy initiation after surgery for stage III colon cancer. Cancer. 2006 Dec 1;107(11):2581-8.

37. Gao P, Huang X-Z, Song Y-X, Sun J-X, Chen X-W, Sun Y, et al. Impact of timing of adjuvant chemotherapy on survival in stage III colon cancer: a population-based study. BMC Cancer. 2018 01;18(1):234.

38. Kim YW, Choi EH, Kim BR, Ko W-A, Do Y-M, Kim IY. The impact of delayed commencement of adjuvant chemotherapy (eight or more weeks) on survival in stage II and III colon cancer: a national population-based cohort study. Oncotarget. 2017 Oct 3;8(45):80061-72.

39. Turner MC, Farrow NE, Rhodin KE, Sun Z, Adam MA, Mantyh CR, et al. Delay in Adjuvant Chemotherapy and Survival Advantage in Stage III Colon Cancer. J Am Coll Surg. 2018 Apr;226(4):670-8.

40. Grothey A, Sobrero AF, Shields AF, Yoshino T, Paul J, Taieb J, et al. Duration of Adjuvant Chemotherapy for Stage III Colon Cancer. N Engl J Med. 2018 29;378(13):117788.

41. Sadahiro S, Tsuchiya T, Sasaki K, Kondo K, Katsumata K, Nishimura G, et al. Randomized phase III trial of treatment duration for oral uracil and tegafur plus leucovorin as adjuvant chemotherapy for patients with stage IIB/III colon cancer: final results of JFMC330502. Ann Oncol Off J Eur Soc Med Oncol. 2015 Nov;26(11):2274-80.

42. O'Connell MJ, Laurie JA, Kahn M, Fitzgibbons RJ, Erlichman C, Shepherd L, et al. Prospectively randomized trial of postoperative adjuvant chemotherapy in patients with highrisk colon cancer. J Clin Oncol Off J Am Soc Clin Oncol. 1998 Jan;16(1):295-300.

43. Haller DG, Catalano PJ, Macdonald JS, O'Rourke MA, Frontiera MS, Jackson DV, et al. Phase III study of fluorouracil, leucovorin, and levamisole in high-risk stage II and III colon cancer: final report of Intergroup 0089. J Clin Oncol Off J Am Soc Clin Oncol. 2005 Dec $1 ; 23(34): 8671-8$.

44. Chau I, Norman AR, Cunningham D, Iveson T, Hill M, Hickish T, et al. Longitudinal quality of life and quality adjusted survival in a randomised controlled trial comparing six months of bolus fluorouracil/leucovorin vs. twelve weeks of protracted venous infusion fluorouracil as adjuvant chemotherapy for colorectal cancer. Eur J Cancer Oxf Engl 1990. 2005 Jul; $41(11): 1551-9$.

45. Sobrero A, Lonardi S, Rosati G, Di Bartolomeo M, Ronzoni M, Pella N, et al. FOLFOX or CAPOX in Stage II to III Colon Cancer: Efficacy Results of the Italian Three or Six Colon Adjuvant Trial. J Clin Oncol Off J Am Soc Clin Oncol. 2018 May 20;36(15):1478-85.

46. André T, Vernerey D, Mineur L, Bennouna J, Desrame J, Faroux R, et al. Three Versus 6 Months of Oxaliplatin-Based Adjuvant Chemotherapy for Patients With Stage III Colon Cancer: Disease-Free Survival Results From a Randomized, Open-Label, International Duration Evaluation of Adjuvant (IDEA) France, Phase III Trial. J Clin Oncol Off J Am Soc Clin Oncol. 2018 May 20;36(15):1469-77. 
47. Kotaka M, Yamanaka T, Yoshino T, Manaka D, Eto T, Hasegawa J, et al. Safety data from the phase III Japanese ACHIEVE trial: part of an international, prospective, planned pooled analysis of six phase III trials comparing 3 versus 6 months of oxaliplatin-based adjuvant chemotherapy for stage III colon cancer. ESMO Open. 2018;3(3):e000354.

48. Iveson TJ, Kerr RS, Saunders MP, Cassidy J, Hollander NH, Tabernero J, et al. 3 versus 6 months of adjuvant oxaliplatin-fluoropyrimidine combination therapy for colorectal cancer (SCOT): an international, randomised, phase 3, non-inferiority trial. Lancet Oncol. 2018 Apr;19(4):562-78.

49. Lonardi S, Sobrero A, Rosati G, Di Bartolomeo M, Ronzoni M, Aprile G, et al. Phase III trial comparing 3-6 months of adjuvant FOLFOX4/XELOX in stage II-III colon cancer: safety and compliance in the TOSCA trial. Ann Oncol Off J Eur Soc Med Oncol. 2016;27(11):2074-81.

50. FOxTROT Collaborative Group. Feasibility of preoperative chemotherapy for locally advanced, operable colon cancer: the pilot phase of a randomised controlled trial. Lancet Oncol. 2012 Nov;13(11):1152-60.

51. Jakobsen A, Andersen F, Fischer A, Jensen LH, Jørgensen JCR, Larsen O, et al. Neoadjuvant chemotherapy in locally advanced colon cancer. A phase II trial. Acta Oncol Stockh Swed. 2015 Nov;54(10):1747-53.

52. Karoui M, Rullier A, Piessen G, Legoux J-L, Barbier E, De Chaisemartin C, et al. Neoadjuvant FOLFOX 4 versus FOLFOX 4 plus cetuximab versus immediate surgery for high-risk stage II and III colon cancers: A phase II multicentre randomised controlled trial (PRODIGE 22). Annals of Oncology (2017) 28 (suppl_5):v158-v208.

10.1093/annonc/mdx393;

53. Sargent DJ, Goldberg RM, Jacobson SD, Macdonald JS, Labianca R, Haller DG, et al. A pooled analysis of adjuvant chemotherapy for resected colon cancer in elderly patients. N Engl J Med. 2001 Oct 11;345(15):1091-7.

54. Mayer B, Sander S, Paschke S, Henne-Bruns D, Link K-H, Kornmann M, et al. Stratified Survival Analysis After Adjuvant Chemotherapy of Colon Cancer Reveals a Benefit for Older Patients. Anticancer Res. 2015 Oct;35(10):5587-93.

55. Haller DG, O'Connell MJ, Cartwright TH, Twelves CJ, McKenna EF, Sun W, et al. Impact of age and medical comorbidity on adjuvant treatment outcomes for stage III colon cancer: a pooled analysis of individual patient data from four randomized, controlled trials. Ann Oncol Off J Eur Soc Med Oncol. 2015 Apr;26(4):715-24.

56. Tournigand C, André T, Bonnetain F, Chibaudel B, Lledo G, Hickish T, et al. Adjuvant therapy with fluorouracil and oxaliplatin in stage II and elderly patients (between ages 70 and 75 years) with colon cancer: subgroup analyses of the Multicenter International Study of Oxaliplatin, Fluorouracil, and Leucovorin in the Adjuvant Treatment of Colon Cancer trial. J Clin Oncol Off J Am Soc Clin Oncol. 2012 Sep 20;30(27):3353-60.

57. Sanoff HK, Carpenter WR, Stürmer T, Goldberg RM, Martin CF, Fine JP, et al. Effect of adjuvant chemotherapy on survival of patients with stage III colon cancer diagnosed after age 75 years. J Clin Oncol Off J Am Soc Clin Oncol. 2012 Jul 20;30(21):2624-34.

58. McCleary NJ, Meyerhardt JA, Green E, Yothers G, de Gramont A, Van Cutsem E, et al. Impact of age on the efficacy of newer adjuvant therapies in patients with stage II/III colon cancer: findings from the ACCENT database. J Clin Oncol Off J Am Soc Clin Oncol. 2013 Jul 10;31(20):2600-6.

59. Konishi T, Shimada Y, Hsu M, Tufts L, Jimenez-Rodriguez R, Cercek A, et al. Association of Preoperative and Postoperative Serum Carcinoembryonic Antigen and Colon Cancer Outcome. JAMA Oncol. 2018 Mar 1;4(3):309-15.

60. Auclin E, Taieb J, Lepage C, Aparicio T, Faroux R, Mini E, et al. Carcinoembryonic antigen levels and survival in stage III colon cancer : post hoc analysis of the MOSAIC and PETACC-8 trials. Cancer Epidemiol Biomarkers Prev. In press..

61. Auclin E, André T, Taieb J, Benetkiewicz M, de Gramont A, Vernerey D. Low-level postoperative carcinoembryonic antigen improves survival outcomes stratification in patients with stage II colon cancer treated with standard adjuvant treatments. Eur J Cancer Oxf Engl 1990. $2018 \mathrm{Jul} ; 97: 55-6$. 
62. Margalit O, Mamtani R, Yang Y-X, Reiss KA, Golan T, Halpern N, et al. Assessing the prognostic value of carcinoembryonic antigen levels in stage I and II colon cancer. Eur $\mathrm{J}$ Cancer Oxf Engl 1990. 2018 Mar 1;94:1-5.

63. Kim CG, Ahn JB, Jung M, Beom SH, Heo SJ, Kim JH, et al. Preoperative Serum Carcinoembryonic Antigen Level as a Prognostic Factor for Recurrence and Survival After Curative Resection Followed by Adjuvant Chemotherapy in Stage III Colon Cancer. Ann Surg Oncol. 2017 Jan;24(1):227-35.

64. Yothers G, O'Connell MJ, Lee M, Lopatin M, Clark-Langone KM, Millward C, et al. Validation of the 12-gene colon cancer recurrence score in NSABP C-07 as a predictor of recurrence in patients with stage II and III colon cancer treated with fluorouracil and leucovorin (FU/LV) and FU/LV plus oxaliplatin. J Clin Oncol Off J Am Soc Clin Oncol. 2013 Dec 20;31(36):4512-9.

65. Jiang Y, Casey G, Lavery IC, Zhang Y, Talantov D, Martin-McGreevy M, et al. Development of a clinically feasible molecular assay to predict recurrence of stage II colon cancer. J Mol Diagn JMD. 2008 Jul;10(4):346-54.

66. Salazar R, Roepman P, Capella G, Moreno V, Simon I, Dreezen C, et al. Gene expression signature to improve prognosis prediction of stage II and III colorectal cancer. J Clin Oncol Off J Am Soc Clin Oncol. 2011 Jan 1;29(1):17-24.

67. Galon J, Costes A, Sanchez-Cabo F, Kirilovsky A, Mlecnik B, Lagorce-Pagès C, et al. Type, density, and location of immune cells within human colorectal tumors predict clinical outcome. Science. 2006 Sep 29;313(5795):1960-4.

68. Galon J, Mlecnik B, Bindea G, Angell HK, Berger A, Lagorce C, et al. Towards the introduction of the "Immunoscore" in the classification of malignant tumours. J Pathol. 2014 Jan;232(2):199-209.

69. Galon J, Fridman W-H, Pagès F. The adaptive immunologic microenvironment in colorectal cancer: a novel perspective. Cancer Res. 2007 Mar 1;67(5):1883-6.

70. Galon J, Mlecnik B, Marliot F, Ou F-S, Bifulco CB, Lugli A, et al. Validation of the Immunoscore (IM) as a prognostic marker in stage I/II/III colon cancer: Results of a worldwide consortium-based analysis of 1,336 patients. J Clin Oncol [Internet]. 2016 [cited 2016 Dec 14];34(suppl; abstr 3500). Available from:

http://meetinglibrary.asco.org/content/168666-176

71. Emile J-F, Malicot KL, Tabernero J, Mini E, Folprecht G, Laethem J-LV, et al.

Validation of the prognostic impact of lymphocyte infiltration (LI) in patients (pts) with stage III colon cancer (CC) treated with adjuvant FOLFOX+/- cetuximab: A PETACC8 translational study. J Clin Oncol [Internet]. 2016 [cited 2016 Dec 14];34(suppl 4S; abstr 553). Available from: http://meetinglibrary.asco.org/content/158705-173

72. Pagès F, Mlecnik B, Marliot F, Bindea G, Ou F-S, Bifulco C, et al. International validation of the consensus Immunoscore for the classification of colon cancer: a prognostic and accuracy study. Lancet Lond Engl. 2018 May 26;391(10135):2128-39.

73. Galon J, Hermitte F, Mlecnik B, Marliot F, Bifulco CB, Lugli A, et al. Immunoscore clinical utility to identify good prognostic colon cancer stage II patients with high-risk clinicopathological features for whom adjuvant treatment may be avoided. J Clin Oncol 37, 2019 (suppl 4; abstr 487).

74. Taieb J, Zaanan A, Le Malicot K, Julié C, Blons H, Mineur L, et al. Prognostic Effect of BRAF and KRAS Mutations in Patients With Stage III Colon Cancer Treated With Leucovorin, Fluorouracil, and Oxaliplatin With or Without Cetuximab: A Post Hoc Analysis of the PETACC-8 Trial. JAMA Oncol. 2016 Jan 14;1-11.

75. Taieb J, Le Malicot K, Shi Q, Penault-Llorca F, Bouché O, Tabernero J, et al. Prognostic Value of BRAF and KRAS Mutations in MSI and MSS Stage III Colon Cancer. J Natl Cancer Inst. 2017;109(5).

76. Gallois C, Taieb J, Le Corre D, Le Malicot K, Tabernero J, Mulot C, et al. Prognostic Value of Methylator Phenotype in Stage III Colon Cancer Treated with Oxaliplatin-based Adjuvant Chemotherapy. Clin Cancer Res Off J Am Assoc Cancer Res. 2018 Oct 1;24(19):4745-53.

77. Gallois C, Laurent-Puig P, Taieb J. Methylator phenotype in colorectal cancer: A 
prognostic factor or not? Crit Rev Oncol Hematol. 2016 Mar;99:74-80.

78. Hinoi T, Tani M, Lucas PC, Caca K, Dunn RL, Macri E, et al. Loss of CDX2 expression and microsatellite instability are prominent features of large cell minimally differentiated carcinomas of the colon. Am J Pathol. 2001 Dec;159(6):2239-48.

79. Lugli A, Tzankov A, Zlobec I, Terracciano LM. Differential diagnostic and functional role of the multi-marker phenotype CDX2/CK20/CK7 in colorectal cancer stratified by mismatch repair status. Mod Pathol Off J U S Can Acad Pathol Inc. 2008 Nov;21(11):140312.

80. Baba Y, Nosho K, Shima K, Freed E, Irahara N, Philips J, et al. Relationship of CDX2 loss with molecular features and prognosis in colorectal cancer. Clin Cancer Res Off J Am Assoc Cancer Res. 2009 Jul 15;15(14):4665-73.

81. Bae JM, Lee TH, Cho N-Y, Kim T-Y, Kang GH. Loss of CDX2 expression is associated with poor prognosis in colorectal cancer patients. World J Gastroenterol. 2015 Feb 7;21(5):1457-67.

82. Dalerba P, Sahoo D, Paik S, Guo X, Yothers G, Song N, et al. CDX2 as a Prognostic Biomarker in Stage II and Stage III Colon Cancer. N Engl J Med. 2016 Jan 21;374(3):21122.

83. Liao X, Lochhead P, Nishihara R, Morikawa T, Kuchiba A, Yamauchi M, et al. Aspirin use, tumor PIK3CA mutation, and colorectal-cancer survival. N Engl J Med. 2012 Oct $25 ; 367(17): 1596-606$.

84. $\mathrm{Ng} \mathrm{K}$, Meyerhardt JA, Chan AT, Sato K, Chan JA, Niedzwiecki D, et al. Aspirin and COX-2 inhibitor use in patients with stage III colon cancer. J Natl Cancer Inst. 2015 Jan;107(1):345.

85. Fan G, Zhang K, Yang X, Ding J, Wang Z, Li J. Prognostic value of circulating tumor DNA in patients with colon cancer: Systematic review. PloS One. 2017;12(2):e0171991.

86. Lecomte T, Berger A, Zinzindohoué F, Micard S, Landi B, Blons H, et al. Detection of free-circulating tumor-associated DNA in plasma of colorectal cancer patients and its association with prognosis. Int J Cancer. 2002 Aug 10;100(5):542-8.

87. Tie J, Wang Y, Tomasetti C, Li L, Springer S, Kinde I, et al. Circulating tumor DNA analysis detects minimal residual disease and predicts recurrence in patients with stage II colon cancer. Sci Transl Med. 2016 Jul 6;8(346):346ra92.

88. Overman MJ, McDermott R, Leach JL, Lonardi S, Lenz H-J, Morse MA, et al. Nivolumab in patients with metastatic DNA mismatch repair-deficient or microsatellite instability-high colorectal cancer (CheckMate 142): an open-label, multicentre, phase 2 study. Lancet Oncol. 2017;18(9):1182-91.

89. Weber J, Mandala M, Del Vecchio M, Gogas HJ, Arance AM, Cowey CL, et al. Adjuvant Nivolumab versus Ipilimumab in Resected Stage III or IV Melanoma. N Engl J Med. 2017 09;377(19):1824-35.

90. Sartore-Bianchi A, Trusolino L, Martino C, Bencardino K, Lonardi S, Bergamo F, et al. Dual-targeted therapy with trastuzumab and lapatinib in treatment-refractory, KRAS codon 12/13 wild-type, HER2-positive metastatic colorectal cancer (HERACLES): a proof-ofconcept, multicentre, open-label, phase 2 trial. Lancet Oncol. 2016 Jun;17(6):738-46. 